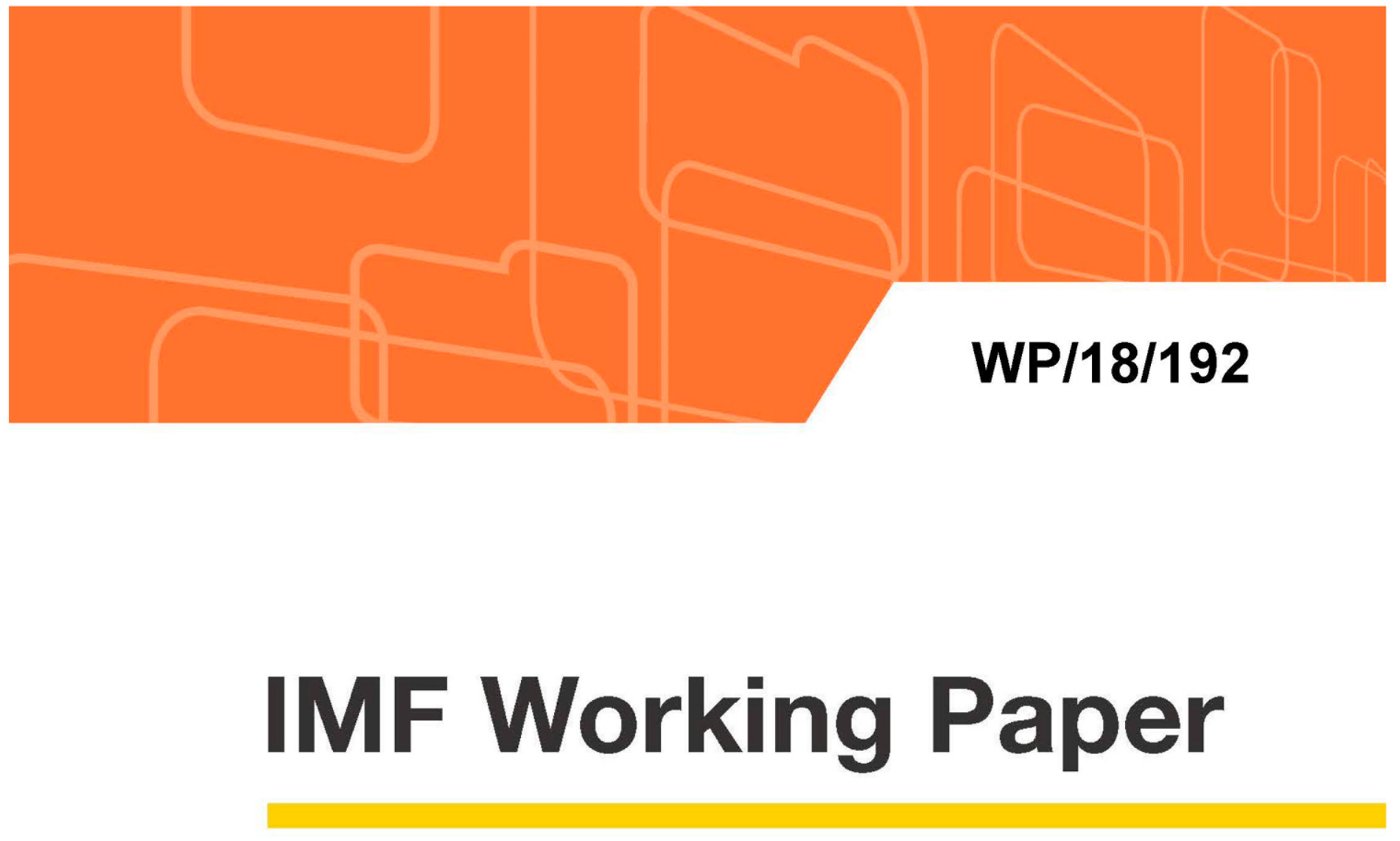

\title{
Banking in a Steady State of Low Growth and Interest
}

Rates

by Qianying Chen, Mitsuru Katagiri, and Jay Surti

IMF Working Papers describe research in progress by the author(s) and are published to elicit comments and to encourage debate. The views expressed in IMF Working Papers are those of the author(s) and do not necessarily represent the views of the IMF, its Executive Board, or IMF management.

$$
\text { I N T E R N A T I O N A L M O N E T A R Y F U N D }
$$




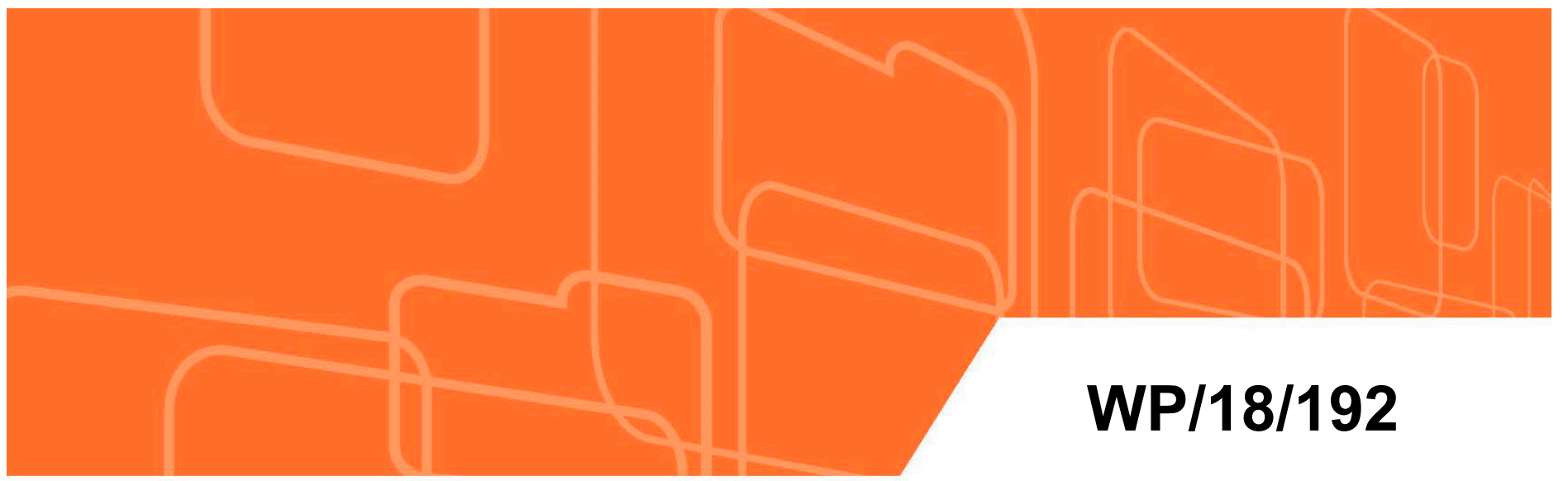

\section{IMF Working Paper}

\section{Banking in a Steady State of Low Growth and Interest}

Rates

by Qianying Chen, Mitsuru Katagiri, and Jay Surti

IMF Working Papers describe research in progress by the author(s) and are published to elicit comments and to encourage debate. The views expressed in IMF Working Papers are those of the author(s) and do not necessarily represent the views of the IMF, its Executive Board, or IMF management.

$$
\text { I N T E R N A T I O N A L M O N E T A R Y F U N D }
$$




\title{
IMF Working Paper
}

MCM

\section{Banking in a Steady State of Low Growth and Interest Rates ${ }^{1}$ \\ Prepared by Qianying Chen, Mitsuru Katagiri and Jay Surti}

Authorized for distribution by Claudio Raddatz

August 2018

\section{IMF Working Papers describe research in progress by the author(s) and are published to elicit comments and to encourage debate. The views expressed in IMF Working Papers are those of the author(s) and do not necessarily represent the views of the IMF, its Executive Board, or IMF management.}

\begin{abstract}
A prolonged low-interest-rate environment presents a significant challenge to banks and is likely to entail major changes to their business models over the long-run. Lower returns to maturity transformation in the face of flatter yield curves and an inability to offer deposit rates significantly below zero combine to compress bank earnings in this environment. Smaller, deposit-funded, less diversified banks are hurt most, increasing consolidation pressures and reach-for-yield incentives, presenting new financial stability challenges. To the extent that such an economic environment reflects a new, steady-state with lower equilibrium growth driven by population aging and slower productivity growth, lower credit demand is likely to drive banking toward provision of fee-based, utility services.
\end{abstract}

JEL Classification Numbers: E43, E52, G21, G32, L11, L22, L25

Keywords: Banking, Growth, Interest Rates, Low-for-Long, Prolonged Low Interest Rates

Author's E-Mail Address: qchen2@,imf.org, mkatagiri@imf.org, jsurti@,imf.org

\footnotetext{
${ }^{1}$ The analysis reported in this paper was prepared by the authors for the April 2017 Global Financial Stability Report of the International Monetary Fund. We are grateful to Nicola Tarashev and Kostas Tsatsaronis for discussing their approach to classifying bank business models and to seminar participants at the IMF, the Hong Kong Monetary Authority, and the Monetary Authority of Singapore for helpful feedback.
} 


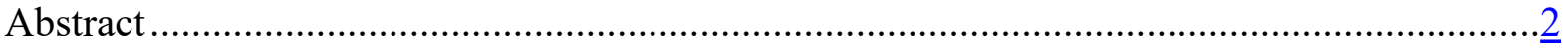

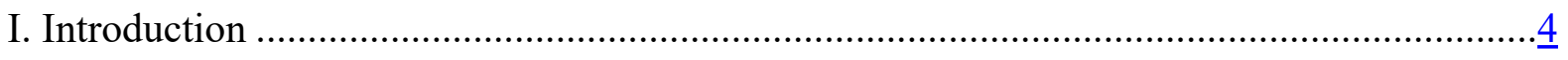

II. A Simple Theory of Banking in a Low-For-Long Steady State ..................................... 1

A. Bank Balance Sheets and the Economic Environment ................................................. 8

B. Bank Profit Maximization and Equilibrium...............................................................

III. Testing the Model—Loan and Deposit Pricing in Japan .............................................16

IV. Cross-Country Experience with Prolonged Low Interest Rates .................................21

A. Defining Periods of Prolonged Low Rates .........................................................

B. Impact of Low-For-Long Episodes on Bank Profits ...................................................22

C. Impact of Changes in Expectations Regarding Low-For-Long Scenarios on

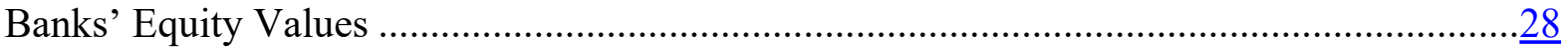

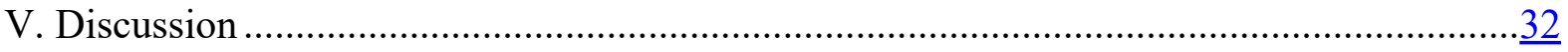

Tables

1. Estimation Result of the Error Correction Model............................................................ $\frac{18}{24}$

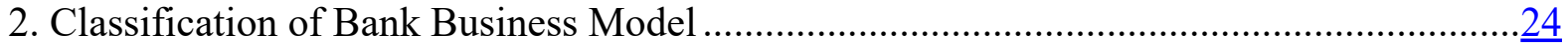

3. Impact of Low-for-long Episodes on Bank Profits: Main Results .................................. 26

4. Impact of Low-for-long Episodes on Bank Profits: Robustness Check ...........................27

5. Impact of Changes in Expectations Regarding a Low-for-Long Scenarios on Bank

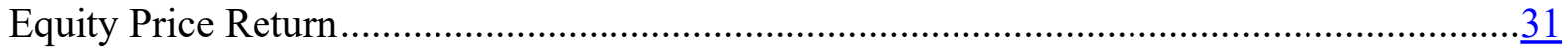

Figures

1. Banking Under Low-for-Long Steady State ....................................................... 15

2. Japan: Evolution of NIMs in Normal and ZLB Equilibria .........................................19

3. Japan: Banks' Adaptation to the Deposit Rate Lower Bound Period ................................20

4. Impact of Forward Rate Surprises on Bank Equity Returns ............................................

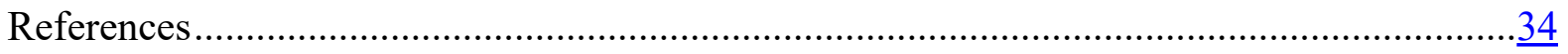




\section{INTRODUCTION}

Advanced economies have recently experienced a long period of insipid growth; low asset returns; low levels, and volatility, of interest rates; and flatter yield curves. This comes on top of the secular decrease in real interest rates over the last three decades. These developments have sparked interest in the question of whether an unusually long and large deviation from a higher equilibrium level of growth is on display, or instead, a transition to a new steady state with lower trend growth and asset returns. A combination of common, slow-moving, structural factors, notably, population aging and the slower growth in the labor force and in productivity could have generated a steady state of low growth and low asset returns, including lower long-term nominal and real interest rates. ${ }^{2}$ Moreover, steadily rising savings and growing demand for advanced-economy financial assets in emerging market economies have also put pressure on interest rates in advanced economies over the past 15 years. ${ }^{3}$

What would be the consequences for financial intermediation, particularly banking, of such a scenario of permanently lower growth and asset returns reflected in low equilibrium rates of interest? If lower rates are accompanied by flatter yield curves, banks' incomes through maturity transformation will take a hit. The evolution of bank business models and the market structure of the banking industry in response to this impact will also likely have consequences for financial stability. For example, search-for-yield, as reflected in widening balance-sheet mismatches or rising exposure to higher risk-higher return businesses may be incentivized, resulting in greater vulnerability to shocks.

This paper studies the long-term impact of an equilibrium with low growth and low interest rates - a low-for-long steady state - on the banking sector and on financial stability. In doing so, it aims to answer several questions of interest. What is the long-term impact on profits and solvency of banks? How does it depend on their business models? Will the existing menu of banking products and services survive? How will these circumstances change the relative importance of banks in the financial system?

Recent studies extend consumption-based equilibrium asset pricing models of the term structure of interest rates to steady-state economies with zero- and near-zero (short-term) interest rates. A common finding is that the yield curve is significantly flatter in a low-forlong steady state. ${ }^{4}$ Since banks earn a significant share of their profits from maturity transformation, the flattening of the equilibrium term structure has negative consequences for

\footnotetext{
${ }^{2}$ Waning population growth weighs directly on economic growth and may pull down real interest rates if it exerts a negative effect on the marginal productivity of capital. Rising longevity also puts downward pressure on real interest rates because households save more to prepare for longer retirement. Gains in total factor productivity reflect, to an important degree, the pace of innovation, which may have slowed because of several factors. The relevant literature is large, and its insights are summarized in a number of recent studies, including among others, IMF (2014); Gordon (2014); Summers (2014); Bean et. al. (2015); Bernanke (2015); Rachel and Smith (2015); and Carvalho et. al. (2016).

${ }^{3}$ Bernanke (2005).

${ }^{4}$ Piazzesi and Schneider (2007) summarize the key insights from the CCAPM literature for the equilibrium term structure. For extensions to the case of zero (short-term) interest rates and low-for-long economies, see Gourio and Ngo (2016), Nakata and Tanaka (2016), IMF (2017), and Katagiri (forthcoming).
} 
long-term profitability which may, eventually, exert a material impact on competitiveness of certain business models triggering corresponding changes in the market structure.

The paper begins by extending a standard, theoretical model of deposit-financed credit intermediation to a low-for-long economy to analyze the implications for equilibrium profit margins, leverage, and sustainability of alternative business models. Lower interest rates may boost banks' earnings in the short term to the degree to which they carry assets at market value and their asset-liability repricing gaps are wider. But, a decrease in the equilibrium interest rate hurts profitability once it falls below a particular, positive threshold. This happens when a lower bound on rates offered on deposits results in a floor on financing costs and a squeeze between the optimal lending rate set by banks and this floor. In such economies, it is smaller, geographically undiversified, deposit-funded banks that suffer the greatest erosion in earnings.

Amongst all advanced economies, Japan's demographic profile, growth, and domestic asset returns including the interest rate and term structure puts it closest to a low-for-long steady state. Consequently, the insights from this theoretical model are tested against data on the evolution of Japanese banks' product pricing over the period 1989-2017. Although market interest rates have remained close to zero since the $1990 \mathrm{~s}$, deposit rates first approached the zero lower bound in the mid-2000s. An assessment of the behavior of these banks' asset returns, funding costs, and market interest rates demonstrates that banks' interest margins have fallen primarily in response to the narrowing of funding spreads once deposit rates hit the zero lower bound in the mid-2000s. This was particularly significant for smaller, deposit funded, domestically oriented banks.

How may we expect banks to respond to the pressures on profits and business models in such a steady state? In order to answer this question, we conduct two separate analyses. First, continuing with the Japanese case, we qualitatively compare and contrast the different adaptation strategies of the large international banks, mid-size Regional banks, and the small Shinkin banks. Second, we expand the geographic focus beyond Japan by studying a large panel of banks from several advanced economies starting in the 1990s through 2017, wherein they experienced a continuous period of near-zero interest rates and a significant flattening of the term structure after the start of the global financial crisis. Some common insights emerge from these two separate analyses. Banks tend to adopt different strategies in reaching for yield, depending on their business models. Smaller, deposit-funded banks typically take on more interest rate risk by increasing the duration of bond portfolios. Large banks are likely to increase risk exposures to foreign countries that offer higher returns (in particular, to emerging market economies) and also rely more heavily on wholesale funding markets.

Over time and in the long-run, we may expect major changes to household and corporate demand for financial products and asset allocation and the menu of services offered by the financial sector as a whole and banks in particular. First, where population aging, rising longevity and slower productivity growth are key forces driving the economy to a low-forlong steady state, aggregate demand for credit will likely decrease and demand for banks' transaction services will likely increase. Consequently, domestic bank lending would likely 
shrink, focusing more on small businesses and less on households and large firms. ${ }^{5}$ Bank business models in advanced economies would tend to evolve toward fee-based and utility banking services. Second, consolidation pressures are likely to emerge as several small banks may be left with unviable business models and be pressured into seeking mergers with larger banks that have more diversified business portfolios. Third, tail risk is likely to increase. On the one hand, as small, domestic economy-facing banks increase duration mismatches, episodes of interest rate volatility will result in larger losses and higher likelihood of bank failure. On the other hand, ventures into foreign markets by larger banks may bring new counterparty and market risks requiring management of a greater number of risk factors.

The key policy challenge in this environment will be to successfully balance multiple objectives. Providing a legal and regulatory framework that facilitates smooth consolidation should go hand in hand with efforts to limit excessive risk taking in an environment with lower expected returns and avoiding a worsening of the too-big-to-fail problem. This includes containing incentives to increase exposure to tail risk from widening maturity mismatches, higher wholesale funding, and foreign-currency exposures. A similar challenge would be to reap benefits from banks' higher engagement in emerging market economies while containing potential, new financial stability risks in home and host countries.

Previous studies have clarified that negative interest rate shocks increase bank profits in the immediate future, but that this favorable impact dissipates the longer interest rates remain low. ${ }^{6}$ Empirical studies covering banks in the United Kingdom and the United States show the existence of separate channels for short- and medium- term effects of interest rate changes on banks' interest margins, profits, and equity valuations. ${ }^{7}$ Banks tend to lose profitability from longer-lasting drops in interest rates in direct proportion to how much they engage in maturity transformation and make use of deposit funding. However, falling interest rates boost bank profits and equity values in the short term due to gains in the value of collateral, valuation gains on mark-to-market assets, and lower default risk on loans repriced to lower interest rates. Brunnermeier and Sannikov (2016) show that macro-financial risk can be decreased by a reduction in interest rates due to the relaxation of agents' debt and collateral constraints. ${ }^{8}$ Our paper's focus is, instead, on the comparative statics of bank profitability induced by permanent decreases in interest rates that, in turn, reflect a decline in

\footnotetext{
${ }^{5}$ Since it is likely that demand for longer-duration fixed income products offered in the market will increase in such an equilibrium, large firms may be able to issue bonds more cheaply and hence may choose to exploit this opportunity and reduce demand for credit from banks. See IMF (2017) for a discussion.

${ }^{6}$ See ESRB (2016) for an extensive discussion.

${ }^{7}$ See, respectively, Alessandri and Nelson (2012) for the United Kingdom and English, van den Heuvel, and Zakrajsek (2012) for the United States. Also, Borio et. al. (2015) and Claessens et. al. (2017) show international evidence on the negative effects of lower interest rates on bank profitability.

${ }^{8}$ More precisely, they show how the adverse short-term impact of an increase in interest rates can be amplified through liquidity spirals (deteriorating net worth increases bank risk aversion, which lowers the market value of assets and lending volumes) and disinflationary spirals (the safe-asset value of cash increases).
} 
the steady state rate of economic growth, and how the profitability impact is shaped by the banks' business models. ${ }^{9}$

Banks appear to respond to falling rates by increasing risk taking through higher leverage. ${ }^{10}$ Dell'Ariccia et. al. (2017) find that U.S. banks' risk-taking responds in this manner to changes in interest rates induced by monetary policy. Focusing on the impact of unconventional monetary easing in the United Kingdom, the United States, and the euro area in recent years, Lambert and Ueda (2014) find that it is associated with deterioration of bank credit risk and delayed balance sheet repair. Chodorow-Reich (2014) does not find evidence of increased risk taking by U.S. banks in response to unconventional monetary policies. The focus of our analysis is on steady-state behavior rather than risk taking implications over the cycle as interest rates change. Nonetheless, the responses of banks with vastly different business models, inferred from our theoretical model and confirmed by both, our empirical analysis and our study of Japanese banks, suggest that tail risk exposure could increase due to banks' adaptation strategies in this environment.

The paper is organized as follows. The next section presents a theoretical model of banking in a low-for-long steady state. Section III applies this model to the case of Japan presenting econometric and qualitative evidence supporting its main insights. Section IV extends the geographic coverage of the empirical analysis of banking in periods of prolonged low interest rates to other advanced economies. Section V concludes with some thoughts on long-run implications for the evolution of banking and for policy.

\section{A Simple Theory OF BANKIng In A Low-For-Long STEAdy State}

The purpose of the model is to show why prolonged low interest rates in the steady-state have negative effects on bank profitability, particularly focusing on a non-linearity around the zero lower bound (ZLB) of nominal interest rates. The analysis is based on an extension of the Monti-Klein model, where banks have some monopolistic power in lending and deposit markets. ${ }^{11}$ It also assumes that there is no term-structure or uncertainty in the economy, with banks being able to flexibly and instantaneously adjust lending and deposit rates in response to changes in equilibrium market interest rates.

In what follows, the first part describes the bank's balance-sheet and profit, as well as the economic environment, including the lending demand function and the deposit supply function. The second part conducts some comparative statics to investigate the effects of lower equilibrium interest rates on bank profitability and illustrates the key insights through numerical simulation.

\footnotetext{
${ }^{9}$ Brunnermeier and Koby (2018) uses an analytical framework similar to Section II of this paper to analyze a different question; viz., whether lowering nominal interest rates can be contractionary at very low rates of interest.

${ }^{10}$ See Dell'Ariccia et. al. (2014) for a theoretical framework.

${ }^{11}$ See Freixas and Rochet (2008), chapter 3, for an exposition of the Monti-Klein model.
} 


\section{A. Bank Balance Sheets and the Economic Environment}

In the economy under consideration, banks' asset portfolios consist of loans $(L)$ and bonds $(B)$ and they raise financing through deposits $(D)$, wholesale funding $(W)$ and equity $(E)$.

$$
L+B=D+W+E
$$

The bank's profit before dividend payments is defined as:

$$
\begin{aligned}
& \pi=\left(R_{L} L+R_{M} B\right)-\left(R_{D} D+R_{M} W\right)-k L \\
& =\left(R_{L}-R_{M}-k\right) L+\left(R_{M}-R_{D}\right) D+R_{M} E,
\end{aligned}
$$

where $R_{L}, R_{D}$, and $R_{M}$ are the lending rate, the deposit rate, and the market rate. ${ }^{12} k$ represents the marginal operational cost of lending. The second equation, which comes from the balance-sheet constraint, implies that the bank's profit consists of the lending revenue, $\left(R_{L}-\right.$ $\left.R_{M}-k\right) L$, the deposit revenue, $\left(R_{M}-R_{D}\right) D$, and the reduction of interest payments due to equity financing, $R_{M} E$.

Loan demand and deposit supply are assumed to be determined as follows:

(Loan demand function) $L=A_{L}\left(R_{L} / g\right)^{-B_{L}}$, where $A_{L}>0$ and $B_{L}>0$.

(Deposit supply function) $D=A_{D}\left(R_{D} / R_{M}\right)^{B_{D}}$, where $A_{D}>0$ and $B_{D}>0$.

Note that $R$ denotes the gross rate of interest (e.g., an interest rate of one percent is described as $R=1.01$ ). $g$ represents the equilibrium rate of economic growth (i.e., the natural rate of interest). Hence, loan demand is a function of the spread between the lending rate and the economic growth rate, varying inversely with this spread. Intuitively, credit demand falls as borrowing costs $\left(R_{L}\right)$ rise in relation to the equilibrium return on investment $(g)$.

Correspondingly, the deposit supply is determined by the spread between the market rate and the deposit rate, varying inversely with this spread. This is because depositors will decide on their asset allocation between bank deposits and other market-based products (e.g., money market funds) depending on the yield differential between the two - the more favorable the relative return on deposits, the greater the share of savings invested in them. Here, deposit

\footnotetext{
${ }^{12}$ Banks are assumed to borrow and lend freely at the rate $R_{M}$. Thus, if the loans-to-deposits ratio is higher than unity, $R_{M}$ is interpreted as the interest rate for wholesale funding on the liability side of banks' balance-sheets. On the other hand, in a country where the loans-to-deposits ratio is below unity, like in Japan, $R_{M}$ is interpreted as the return on government bonds on the asset side of banks' balance-sheets.
} 
spreads are positive, reflecting household liquidity needs. ${ }^{13} B_{L}$ and $B_{D}$ thus represent respectively the interest elasticity of loans and deposits .

\section{B. Bank Profit Maximization and Equilibrium}

The model is solved for two separate cases of economies which are not subject to a ZLB constraint on deposit rates and others which are subject to this constraint. The main case of interest is the second one, because the ZLB on deposit rates is identified as a main concern for bank profitability in a low interest rate environment. While the model does not provide micro foundations for why the deposit rate is constrained by the ZLB, one possible reason for a lower bound is a preference for cash relative to deposits that is a function of their relative rates of return (e.g., Drechsler et. al. 2016).

In each economy, comparative statics for investigating the effects of lower equilibrium interest rates is conducted under the scenario that prolonged low interest rates are induced by low economic growth. ${ }^{14}$ This scenario corresponds to the textbook case wherein the natural rate of interest is determined by the steady state economic growth rate, and central banks set their steady state policy rates at the natural rate. Hence, in this scenario, it will be assumed that market interest rates, $R_{M}$, are equal to the steady-state economic growth rate; i.e., $R_{M}=g$.

Given the market rate, $R_{M}$, and the growth rate, $g$, the bank chooses the lending rate, $R_{L}$, and the deposit rate, $R_{D}$, so as to maximize its profit subject to the balance sheet constraint, the loan demand, and the deposit supply. The equilibrium lending $\left(R_{L}{ }^{*}\right)$ and deposit $\left(R_{D}{ }^{*}\right)$ rates are shown to be:

$$
R_{L}^{*}=\frac{B_{L}}{B_{L}-1}\left(R_{M}+k\right) ; R_{D}^{*}=\frac{B_{D}}{B_{D}-1} R_{M}
$$

It follows that the equilibrium levels of loans $\left(L^{*}\right)$ and deposits $\left(D^{*}\right)$ are:

$$
L^{*}=A_{L}\left(\frac{B_{L}}{B_{L}-1}\right)^{-B_{L}}\left(\frac{R_{M}+k}{g}\right)^{-B_{L}} ; D^{*}=A_{D}\left(\frac{B_{D}}{B_{D}+1}\right)^{B_{D}}
$$

and the bank's profit function can be written as:

$$
\pi^{*}=\left(R_{L}^{*}-R_{M}-k\right) L^{*}+\left(R_{M}-R_{D}^{*}\right) D^{*}+R_{M} E
$$

\footnotetext{
${ }^{13}$ See Nagel (2016) for a discussion on the choice between near-money assets like deposits and other financial assets.

${ }^{14}$ See ESRB (2016) for a comparison with another scenario where low interest rates are a temporary phenomenon.
} 
Those equilibrium values will be used for comparative statics with respect to $R_{M}$.

\section{An economy without the ZLB of nominal interest rates}

Equilibrium interest rates and lending and deposit volumes may be approximated as: ${ }^{15}$

$$
r_{L}^{*}=r_{M}+k+\frac{1}{B_{L}-1} ; r_{D}^{*}=r_{M}-\frac{1}{B_{D}+1}
$$

and

$$
l^{*}=a_{L}-\frac{B_{L}}{B_{L}-1}-B_{L}\left(r_{M}-\ln g+k\right) ; d^{*}=a_{D}-\frac{B_{D}}{B_{D}+1}
$$

The lending rate and the deposit rate imply that their spreads are constant at $k+\frac{1}{B_{L}-1}$ and $\frac{1}{B_{D}+1}$ respectively; ${ }^{16}$ lending in equilibrium is decreasing in the gap between market rates of interest $\left(R_{M}\right)$ and the real return on investment $(g)$; and the deposit volumes are constant.

Comparative statics show that lower interest rates have negative effects on bank profitability, importantly due to the compression of net interest margin (NIM). Since $R_{M}=g$, the equilibrium lending volume is constant with respect to $R_{M}$ :

$$
\begin{aligned}
l^{*} & =a_{L}-\frac{B_{L}}{B_{L}-1}-B_{L}\left(r_{M}-\operatorname{lng}+k\right) \\
& =a_{L}-\frac{B_{L}}{B_{L}-1}-B_{L} k
\end{aligned}
$$

which implies that the first two terms in the bank's profit function, the lending revenue and the deposit revenue, are (approximately) constant and independent of $R_{M}$. Therefore, the bank's profit is now increasing with respect to $R_{M}$ due to the last term of the profit function.

\footnotetext{
15 Small-case letters represent natural logarithms of corresponding prices and quantities.

${ }^{16}$ Since the markup for lending rates and the markdown for deposit rates are not quite high in most advanced economies, the approximation by a logarithm function works well in this context.
} 
Next, defining the bank's equilibrium net interest margin (NIM) as:

$$
\begin{gathered}
N I M^{*}=\frac{\left(R_{L}^{*} L^{*}+R_{M} B^{*}\right)-\left(R_{D}^{*} D^{*}+R_{M} W^{*}\right)}{\left(L^{*}+B^{*}\right)} \\
=\frac{\left(R_{L}^{*}-R_{M}\right) L^{*}+\left(R_{M}-R_{D}^{*}\right) D^{*}+R_{M} E}{\left(L^{*}+B^{*}\right)}
\end{gathered}
$$

it is easily seen that this is increasing with respect to $R_{M}$ :

$$
\frac{\partial N I M^{*}}{\partial R_{M}}=\frac{E}{\left(L^{*}+B^{*}\right)}>0
$$

The compression of NIMs due to a decrease in equilibrium (market) interest rates can be understood as a constant excess return on bank equity. This equilibrium excess return, $\frac{\pi^{*}}{E}-$ $R_{M}$, is defined as $\left(R_{L}^{*}-R_{M}-k\right) \frac{L^{*}}{E}+\left(R_{M}-R_{D}^{*}\right) \frac{D^{*}}{E}$, which implies that, as a result of the bank's optimization, the excess return on bank equity is independent of $R_{M}$. This is intuitive since otherwise the bank's share would give higher excess returns to shareholders in response to lower market returns. The above equation also implies that NIMs of more leveraged banks are less sensitive to movements in equilibrium rates of interest.

We summarize with the following:

Proposition 1. Equilibrium bank profitability experiences a negligible decrease if equilibrium market interest rates fall with a decline in the steady state rate of economic growth.

\section{An economy with the ZLB on deposit rates}

It is usually difficult for banks to set negative deposit rates even when market rates are almost zero. To take this into account, it is now assumed that the equilibrium deposit rate is set equal to zero; i.e., $\widetilde{R_{D}^{*}}=1$, whenever $R_{M}$ is sufficiently low so that the optimal deposit rate $r_{D}^{*}=r_{M}-\frac{1}{B_{D}+1}<0 .{ }^{17}$ If equilibrium market interest rates continue to decrease beyond this point, deposits become ever more (relatively) attractive as a savings vehicle compared to bonds due to the ZLB constraint on their remuneration. Hence, unsurprisingly, the equilibrium level of savings deposited in the banking sector is a decreasing function of

\footnotetext{
${ }^{17}$ The details of how to solve for the bank's optimal decision in the economy with the ZLB are not shown because they entail somewhat tedious calculations, albeit the bank's optimality conditions are characterized by Kuhn-Tucker conditions with the inequality condition for the ZLB of deposit rates.
} 
market interest rates in such a situation. Precisely, the deposit supply function may be rewritten (by setting $\widetilde{R_{D}^{*}}=1$ ), as $\widetilde{d^{*}}=a_{D}-B_{D} r_{M}>d^{*}$, which implies that the deposit volume increases in the face of lower equilibrium interest rates as has been observed in Japan. On the other hand, since the lending business is not influenced by the ZLB on deposit rates, the loan-to-deposit ratio, $\frac{\widetilde{L^{*}}}{\widetilde{D^{*}}}=\frac{L^{*}}{\widetilde{D^{*}}}$ is increasing with respect to market interest rates. Finally, if equilibrium interest rates decrease below the level at which the deposit rate hits its ZLB, the increase in the share of savings invested in deposits implies that bank leverage increases.

At the ZLB of deposit rates, the bank's profit becomes $\widetilde{\pi^{*}}=\left(R_{L}^{*}-R_{M}-k\right) L^{*}+\left(R_{M}-\right.$ 1) $\widetilde{D^{*}}+R_{M} E$. As described in the economy without the ZLB, the lending spread, $R_{L}^{*}-R_{M}$, and the lending volume, $L^{*}$, are almost independent of $R_{M}$. From this, it follows that the bank's profit is increasing in $R_{M}$ because the deposit revenue (the second term) can be shown to be increasing in $R_{M}$ and the third term is clearly increasing in $R_{M}{ }^{18}$ Notice that bank profits decrease with a fall in equilibrium interest rates not only because of the reduction in savings on interest through equity financing but also because deposit revenues fall. Hence, once equilibrium interest rates fall to a level corresponding to the ZLB of deposit rates, the profit compression induced by further decreases in the equilibrium rate of interest (and growth) is larger than before deposit rates hit the ZLB. ${ }^{19}$

We summarize with the following:

Proposition 2. When deposit rates are constrained by the ZLB, lower equilibrium market interest rates that reflect a decrease in the steady state growth rate of the economy translate into a negative impact on bank profitability that is larger than when deposit rates are not so constrained.

\section{Negative natural rates of interest at the ZLB}

Negative natural rates of interest; i.e., negative equilibrium real interest rates, have been cited as a challenge for policy makers in countries experiencing lower steady state growth rates and domestic asset returns, including Japan and some advanced European economies. Below a floor, negative natural rates $(g<1)$ would be difficult for central banks to manage by

\footnotetext{
${ }^{18}$ Deposit revenues increase with market rates of interest because the ZLB-driven increase in the deposit spread dominates the decrease in deposit revenue generated by the fall in deposit volumes triggered by the rising spread between bond returns and (zero) deposit rates.

${ }^{19}$ Note that the fall in steady state bank profitability at lower equilibrium rates of interest obtains despite higher operational efficiency of the lending business at lower interest rates. Specifically, the cost ratio, $\frac{k L^{*}}{L^{*}+\widetilde{B}^{*}}$, is decreasing with respect to $R_{M}$ at the ZLB of $R_{D}$, since the lending volume is independent of $R_{M}$ whereas bond holdings increase as $R_{M}$ falls. Such a pattern has been observed in Japan.
} 
lowering nominal policy rates ever further into negative territory (Viñals et. al. 2016). From a modeling perspective, the implications of this for bank profits is best seen by setting a ZLB on $R_{M}$; i.e., constraining $R_{M} \geq 1$.

Fixing $R_{M}=1$, the equilibrium lending rate is constant at $r_{L}^{*}=k+\frac{1}{B_{L}-1}$; i.e., the optimal lending spread is constant (since $r_{M}=0$ ) and independent of $g$. Hence, the equilibrium level of lending becomes $l^{*}=a_{L}-B_{L}\left(r_{L}^{*}-\ln g\right)$. The equilibrium lending volume decreases with the natural rate of interest because borrowing costs no longer adjust in response to deteriorating steady-state growth prospects given that nominal interest rates are at their ZLB and the lending spread is constant. Bank profits in equilibrium are $\pi^{*}=\left(R_{L}^{*}-k-1\right) L^{*}+E$, which is also an increasing function of $g$ reflecting the positive impact of higher steady-state growth on credit intermediation. We summarize with the following:

Proposition 3. When $R_{M}$ is constrained by the $Z L B$, a decline in $g$ exerts an additional negative effect on the bank's profit through the decline in lending volume. ${ }^{20}$

\section{Does geographic diversification make bank profits more resilient?}

Some large banks can access international lending businesses in addition to domestic ones. If this is the case, the bank's balance sheet becomes:

$$
L+B+F=D+W+E
$$

where $F$ represents the lending volume in foreign markets. The bank's profit before dividend payments is now defined as:

$$
\begin{aligned}
\pi & =\left(R_{L}+R_{F} F+R_{M} B\right)-\left(R_{D} D+R_{M} W\right)-k(L+F) \\
& =\left(R_{L}-R_{M}-k\right) L+\left(R_{F}-R_{M}-k\right) F+\left(R_{M}-R_{D}\right) D+R_{M} E,
\end{aligned}
$$

where $R_{F}$ is the interest rate charged on foreign loans. Foreign loan demand, $F$, is specified as

$$
F=A_{F}\left(\frac{R_{F}}{g_{F}}\right)-B_{F},
$$

where $A_{F}>0, B_{F}>0$, and $g_{F}$ represents the steady-state growth rate in foreign countries. ${ }^{21}$

\footnotetext{
20 The result can be applied to any case where $g<R_{M}$ and $R_{D}=1$.

${ }^{21}$ In choosing this specification, it is implicitly assumed that the bank from the domestic economy engages in monopolistic competition in a foreign country's banking industry (say, an advanced economy lender providing banking services in an emerging market economy).
} 
In equilibrium, the lending rate $\left(R_{F}{ }^{*}\right)$ and international lending volume $\left(F^{*}\right)$ is determined as:

$$
r_{F}^{*}=r_{M}+k+\frac{1}{B_{F}-1}
$$

and

$$
f^{*}=a_{F}-\frac{B_{F}}{B_{F}-1}-B_{F}\left(r_{M}-\ln g_{F}+k\right) .
$$

In equilibrium, the lending spread earned on foreign loans is invariant in domestic equilibrium market rates. Moreover, if the steady-state growth rate of the foreign economy is independent of the equilibrium interest rate in the domestic economy, the bank will increase its share of foreign lending volume when $R_{M}$ falls; i.e., a substitution effect of changing relative returns in different lending markets. ${ }^{22}$ The expansion of foreign lending can mitigate the decline in bank profits in response to lower steady state growth rate and market interest rates in the home country because it serves to cushion the adverse impact on average NIM and hence, on net interest income. The share of international lending businesses in terms of the lending volume and interest income would increase because the domestic lending is independent of $R_{M}$. This reflects the utilization of part of the deposit inflows incentivized by falling interest rates under the ZLB of domestic deposit rates to fund an increase in exposure to higher return foreign loans. In order to meet regulatory requirements on management of exchange rate risk, banks may increase exposure to (swap) counterparties. In reality, of course, banks may also actively seek to raise wholesale funding in foreign currency to raise exposure to foreign loans. Note that the ability of banks to expand into foreign markets for higher returns will, in practice, be a function of its incumbent business model. It is the larger banks with a more diversified portfolio of businesses that are better placed to finance and manage foreign expansions than small, regionally-focused depositories and lenders.

Proposition 4. If the bank has an opportunity to invest in a foreign lending market, the bank can mitigate the negative effects of a decline in $g$ by extending the loans in foreign markets.

\footnotetext{
${ }^{22}$ Note that, even with international businesses, equilibrium values for domestic lending and deposits are not changed at all.
} 


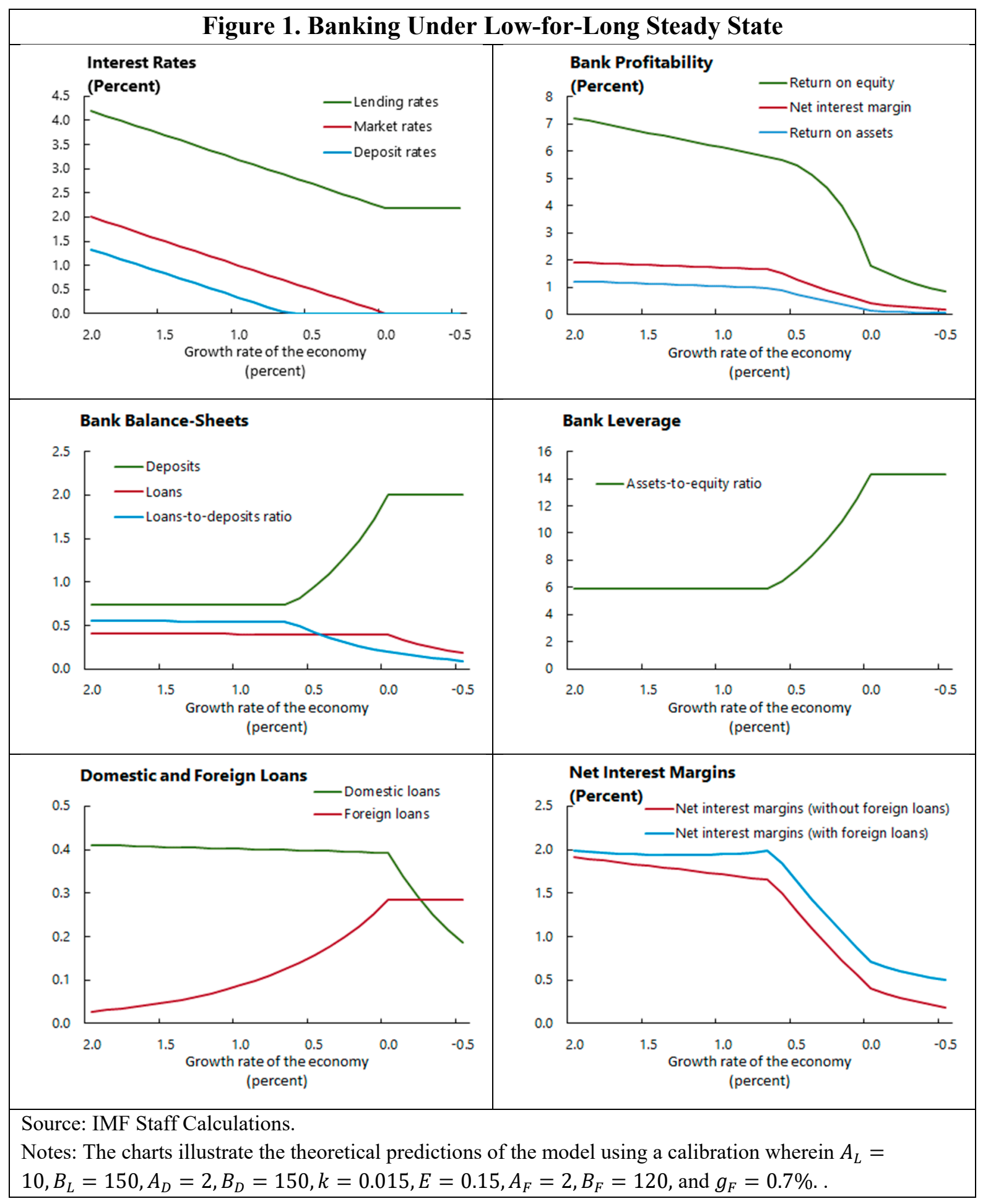

Figure 1 shows a numerical simulation based on the model's solution, summarizing the theoretical implications for the banking sector of a low-for-long steady state. For all charts in the figure, the horizontal axis represents the growth rate of the economy, $g$. First, the top-left chart shows that when the steady state growth rate of the economy $\left(g=R_{M}\right)$ is higher than around 0.7 percent, the equilibrium deposit rate is positive. In this region, as the growth rate 
decreases, the lending and deposit spreads as well as the loans and deposit volumes are (almost) constant with a slight decrease in the NIM and bank profitability. When steady state growth rate falls below 0.7 percent (but is still positive), the deposit rate is now constrained by the ZLB. In this region, further decreases in $g=R_{M}$ results in a compression of the deposit spread which triggers deposit inflows and a significant decline in bank profits. Since the lending spread and volumes are constant, falling equilibrium growth and interest rates result in falling loan-to-deposit ratios, NIMs and profit margins. Finally, when $g$ falls below zero and $R_{M}$ is itself constrained by the ZLB, the lending and deposit spreads are constant, loan volumes fall while the deposit stock remains constant resulting in further decreases in the loan-to-deposit ratio, NIM and bank profits. Finally, the bottom two figures show that the decline in NIM and bank profitability is mitigated by banks increasing the share of foreign loans in their asset portfolio.

\section{Testing the Model-LoAn ANd Deposit Pricing in Japan}

Several implications ensue for business models of different types of banks from the preceding analysis. First, banks that are able to operate internationally would increase their exposure to countries where rates of return remain favorable, notably emerging market economies. Second, they can be expected to increase reliance on wholesale funding in foreign currency (within existing regulatory limits) to finance this expansion. More generally, banks that raise a larger proportion of their funding from capital markets will be less susceptible to the squeeze in interest margins and incomes induced by the deposit rate ZLB. Third, scale efficiencies in managing deposits would imply incentives for consolidation. And, scale efficiencies in the costs of managing wholesale funding would mean that larger banks will be more inclined to seek this form of financing.

The Japanese economy over the past decade provides the closest real-world approximation to a steady state with low growth and natural rates. The insights from the theoretical model can thus be weighed against the experience of Japanese banks over this period. Japan has faced low interest rates for more than a decade. Short-term interest rates have been close to zero since the Bank of Japan adopted the zero interest rate policy in the early 2000s, with the exception of the extraordinary period of 2007-08. Long-term interest rates have also been low since the early 2000s and recently declined further, particularly after the Bank of Japan adopted policies of quantitative and qualitative monetary easing in 2013 and of negative interest rates in 2016.

Consequently, we lever off the Japanese experience in two ways. First, we test one of the main implications of the theoretical analysis; viz., that bank NIMs are compressed under lower interest rates near and at the ZLB because funding spreads are squeezed rather than lending/ asset spreads (Proposition 2). Second, we offer a broader, qualitative analysis of the 
business model responses of Japanese banks in the aftermath of the ZLB of deposit rates and whether and how well these correspond to the predictions of the model.

\section{Asset returns and funding costs at the ZLB}

We follow Gambacorta (2008) in using an error correction model (ECM) for testing the impact of the ZLB on asset and funding spreads and on bank NIMs in Japan. ${ }^{23}$ The ECM is estimated using data on a panel of Japanese banks for the period 1989 through 2014.

$$
\begin{aligned}
\Delta r_{F, i, t}=-a_{F} & \left(r_{F, i, t-1}-b_{0, F}-\left(b_{1, F}+b_{2, F} \operatorname{Low}_{t-1}\right)\left(r_{M, t-1}-r_{M}^{\prime}\right)\right)+\left(b_{3, F}\right. \\
& \left.+b_{4, F} \operatorname{Low}_{t}\right) \Delta r_{M, t} \\
\Delta r_{A, i, t}=-a_{A}( & \left.r_{A, i, t-1}-b_{0, A}-\left(b_{1, A}+b_{2, A} \operatorname{Low}_{t-1}\right)\left(r_{M, t-1}-r_{M}^{\prime}\right)\right)+\left(b_{3, A}\right. \\
& \left.+b_{4, A} \operatorname{Low}_{t}\right) \Delta r_{M, t}
\end{aligned}
$$

where $r_{F, i, t}$ and $r_{A, i, t}$ are the return on the liabilities and assets of bank $i$ in period $t ; r_{M, t}$ is a risk-free market rate; $a_{F}$ and $a_{A}$ are the speed of error correction. The threshold rate of interest $r_{M}^{\prime}$ denotes the demarcation point of the regime of normal rates of interest where funding and asset spreads are optimized and the low-for-long equilibrium with the ZLB of deposit rates; i.e., $L o w_{t}=1$ if and only if $r_{M, t}<r_{M}^{\prime}$. In the latter regime, the long-term and the short-term relationships of the bank's asset and liability returns with market interest rates changes from $b_{1}$ and $b_{3}$ to $b_{1}+b_{2}$ and $b_{3}+b_{4}$, respectively. ${ }^{24}$

The theoretical model implies that $b_{1, F}$ and $b_{1, A}$ are almost the same, that $b_{2, F}$ and $b_{4, F}$ are negative, and that $b_{2, A}$ is small, or equivalently, that the NIM is almost constant in the normal interest rate regime and decreases in the Low regime due to a compression in bank funding spreads. The estimation results are consistent with the model's predictions (Table 1). First, both $\widehat{b_{1, F}}$ and $\widehat{b_{1, A}}$ are approximately 0.85 , which means that the NIM is almost independent of market interest rates in the steady state with normal market rates of return. Second, $\widehat{b_{2, F}}$ is -0.74 , which means that funding spreads get compressed as equilibrium market rates decline in the ZLB regime of deposit rates. Finally, $\widehat{b_{2, A}}$ is small and statistically insignificant, which

\footnotetext{
${ }^{23}$ See also Neumark and Sharpe (1992), Saunders and Schumacher (2000), and Graeve et al. (2007) for the relationship between bank interest margins and market rates.

${ }^{24}$ In the estimation, the five-year government bond zero coupon yield is used as a proxy of the market rate, $r_{M}$, because: (i) the average maturity of bond investments by Japanese banks is around 3-4 years, (ii) government bonds other than the two-, five-, and ten-year maturity brackets are not actively traded in Japan. Also, the Low regime is defined at the cut-off of 0.9 percent, given the average deposit spread among Japanese banks. The estimation results are, however, robust to other choices for the cut-off point around 0.9 percent.
} 
means that the relationship between asset returns and market interest rates does not change a lot, even at the ZLB.

Looking at the impulse responses in the ECM model, the estimated sensitivity of asset and liability returns to a one percentage point decline in equilibrium market rates is clearly different in the regime of normal interest rates versus the low-for-long case. Comparing equilibria in the normal regime (Figure 2.1), as market interest rates vary in the interval of one-to-two percent (the lower bound being close to the ZLB of the liability rate of return), we see that the equilibrium NIM of banks is almost independent of the level of bond interest rates (Figure 2.3). This is because asset and liability returns have almost equal sensitivity to changes in equilibrium market interest rates above the ZLB of liability returns (i.e., $\widehat{b_{1, F}} \approx$ $\widehat{b_{1, A}}$ ). However, once liability rates of return hit their ZLB (at $r_{M}^{\prime}=0.9$ ), further decreases in $r_{M, t}$ result in compression of funding spreads and almost invariant asset spreads (Figure 2.2) resulting in a sharp compression in NIMs (Figure 2.3), both in the short run and in the long run. Those responses in Figure 2 are consistent with the theoretical results in Section 2: while bank profitability is almost independent of market rates above the ZLB, it non-linearly declines in response to the decrease in market rates due to the compression of funding spread around the ZLB.

\section{Table 1. Estimation Result of the Error Correction Model}

\begin{tabular}{lcccccc}
\hline & \multicolumn{3}{l}{ 1. Long-term equilibrium } & \multicolumn{3}{l}{ 2. Short-term dynamics } \\
Coefficient & b_1 & b_2 & b_0 & a & b_3 & b_4 \\
\hline Asset return & $0.838^{* * *}$ & 0.030 & $0.864^{* * *}$ & $-0.431^{* * *}$ & $0.420^{* * *}$ & $-0.160^{* * *}$ \\
& $(0.006)$ & $(0.024)$ & $(0.014)$ & $(0.006)$ & $(0.005)$ & $(0.015)$ \\
\hline Funding cost & $0.853^{* * *}$ & $-0.743^{* * *}$ & $0.082^{* * *}$ & $-0.544^{* * *}$ & $0.446^{* * *}$ & $-0.386^{* * *}$ \\
& $(0.004)$ & $(0.017)$ & $(0.004)$ & $(0.007)$ & $(0.004)$ & $(0.014)$ \\
\hline
\end{tabular}

Standard errors in parentheses

*** $p<0.01,{ }^{* *} p<0.05, * p<0.1$

Sources: Fitch Connect; and IMF Staff Calculations.

Note: The estimation uses unbalanced panel data from 1989 to 2015 on annual frequency for Japanese banks (Major banks, Regional banks, and Shinkin banks) in Fitch Connect. The asset return is defined as interest income divided earning asset while the funding cost is defined by interest expense divided by total funding. The 5 -year government bond rate, which is used as a proxy for market rates, is taken from the Ministry of Finance webpage. The estimation is conducted by a non-stationary panel regression method with fixed effects. See the description of STATA command "xtpmg" for more details about the estimation method. 


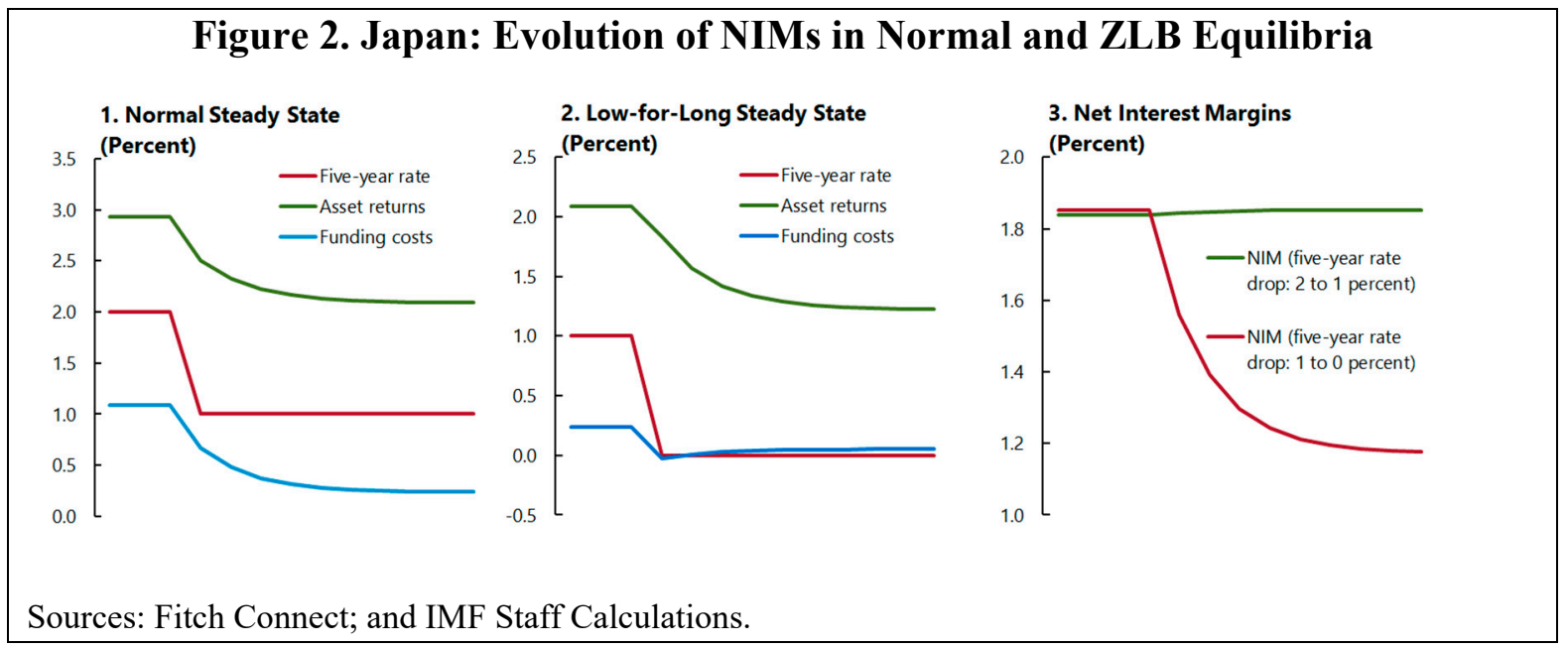

\section{Business models of Japanese banks in the aftermath of the ZLB}

More broadly, the relative performance of Japanese banks across business models also conforms to the theoretical predictions of the model. Resilience to the low-for-long steady state improves with diversification (Figure 3). Smaller, domestically oriented, depositdependent Regional and Shinkin banks have sought to counter the NIM compression primarily through expansion or adjustment of their domestic balance sheets. When benefits to this strategy declined, they engaged in cost cutting and consolidation. Large internationally active banks, on the other hand, have sought to expand the diversification in their income sourcing. This strategy has been more effective, and these banks have faced little pressure to cut costs or to consolidate.

On the assets and earnings side, almost all the growth in these major banks' portfolios can be accounted for by the increase in international loans and securities, through both foreign branches and mergers with and acquisitions of foreign entities. The large banks have expanded their fee businesses outside Japan, including in emerging markets - for example, through the coordination of syndicated loans. Consequently, the share of income from international businesses has risen significantly, consistent with the model's predictions. The large banks have also been able to use their cross-product customer connections to increase noninterest income more effectively through fees and commissions on sales of investment trusts and life insurance products. By contrast, the smaller domestic banks have focused on growing their loan portfolios in urban centers (Regional) and on expanding the maturity of their sovereign bond portfolios (Regional and Shinkin). Success has varied. Pursuing credit spreads has been more profitable, whereas the compression in term premiums has generated a relatively lower increase in returns to Regional and Shinkin banks from extending bond maturities. On the funding side, the large banks source about one-third of funding from capital markets. This has eased the consequences of the compression of domestic funding 
spreads around the deposit rate ZLB relative to Regional and Shinkin banks, whose deposits constitute over 90 percent of their nonequity financing. On operating margins, Regional and Shinkin banks have cut operating costs substantially by rationalizing their branch networks in the face of lower profitability. This is in contrast to the large banks, whose operating cost ratios have been almost flat for the past two decades.

Consolidation has enhanced the effectiveness of strategies to maintain profits in the low-forlong environment. It can raise profitability by both cutting fixed operational costs and by increasing the banks' monopolistic power in deposit and loan markets. Recently, Regional banks pursued consolidation by forming financial groups to enhance their profitability.

Figure 3. Japan: Banks' Adaptation to the Deposit Rate Lower Bound Period
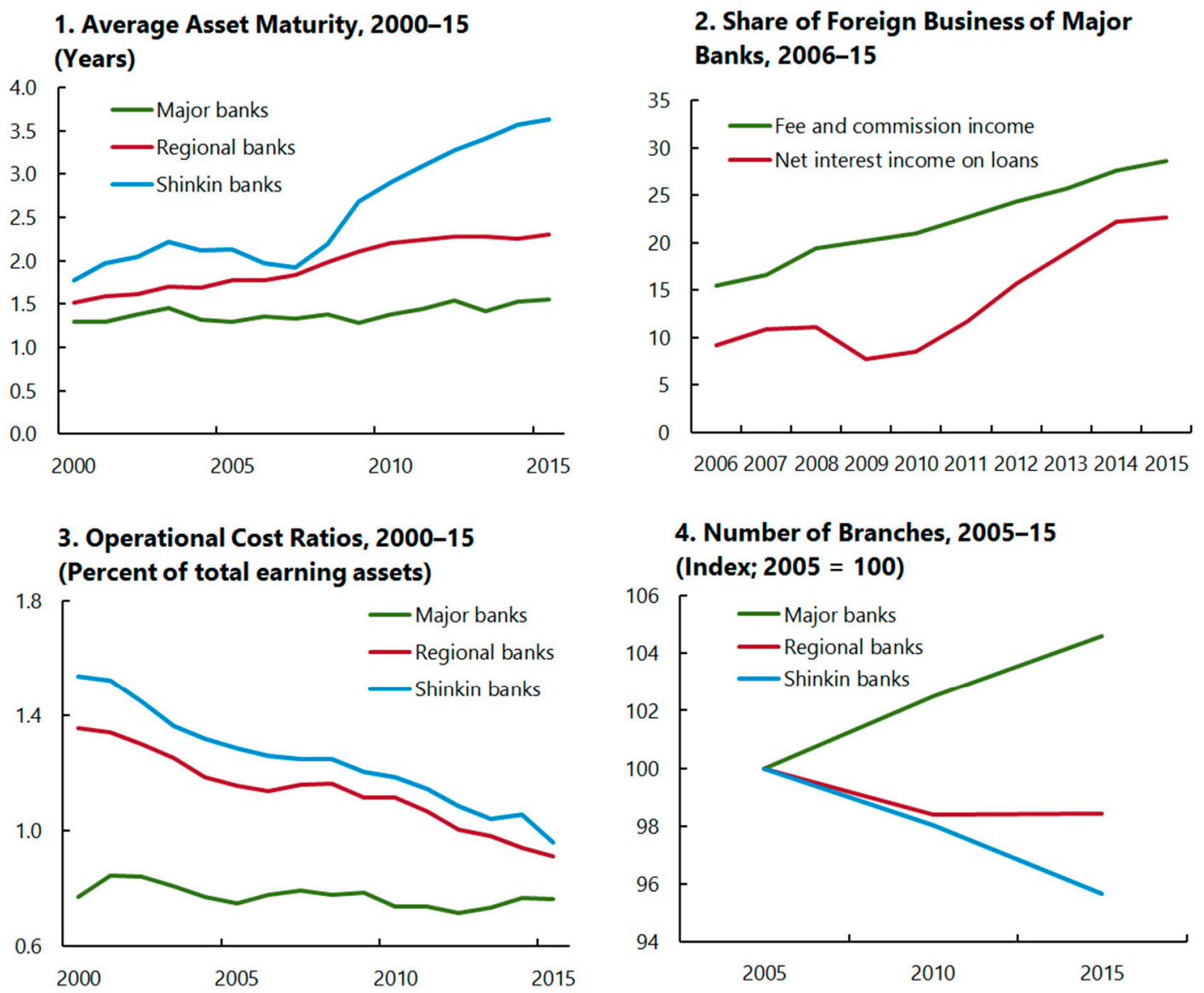

Sources: Bank of Japan; Fitch Connect; Japanese Bankers’ Association; and IMF Staff Calculations.

Alternative strategies have different risk implications. The large banks have maintained stable NIMs and profitability at the cost of higher cross-border market and counterparty risk. In particular, given the growing share of wholesale foreign currency funding used by these banks, the adverse impact of a tightening in these markets could be large. Already, the costs 
of funding in this market have risen significantly due to market friction (Avdjiev et. al. 2016). Shinkin banks have increased interest rate risk by extending the average maturity of domestic bonds, but risk-adjusted returns have nonetheless increased only modestly, given unusually low inflation and interest rate volatility during the past decade.

\section{Cross-Country Experience With Prolonged Low Interest Rates}

We now broaden our empirical evaluation of the impact of periods of prolonged low growth and interest rates beyond Japan in order to assess the robustness of our findings. The crosscountry analysis reported in this section aims to compare bank profitability and equity valuations at times when interest rates are low and are expected to remain low for the foreseeable future, with other periods wherein these conditions do not hold. As in the preceding analysis, this section will continue to examine the relative resilience of bank earnings conditional on their business model. Some periods that are defined as having prolonged low interest rates under these criteria will not necessarily correspond to underlying economic conditions of low long-term equilibrium growth and interest rates. The analysis and results nonetheless provide valuable insights into the likely implications of such a scenario. This will be the case if, in demarcating periods of prolonged low interest rates for the purposes of empirical analysis, one is able to ensure admissibility for only those periods of time when economic growth and nominal and real interest rates have been low for a considerable period. ${ }^{25}$ This is because a significant proportion of temporary effects on earnings and solvency - near-term gains and losses on mark-to-market positions and asset quality changes - have, arguably, already worked themselves out and the estimated effect of low interest rates is closer to the longer-term impact of prolonged low rates.

\section{A. Defining Periods of Prolonged Low Rates}

The approach to defining a period of prolonged low rates of interest is, in general, sensitive to the objectives of the empirical analysis. In this paper, we are interested in two questions.

First, what is the difference in impact on bank profitability of a decrease in interest rates in periods of prolonged low rates relative to other periods? Two important drivers can be hypothesized as a source of differential impact - to the extent that prolonged low rates reflect a low-for-long growth equilibrium, lower rates would not stimulate lending significantly; moreover, as the theoretical analysis suggests, such interest rate movements around a ZLB of deposit rates would result in a negative impact on earnings. So, one should expect that decreases in (short-term) interest rates would trigger a negative or a significantly weaker positive impact in periods of prolonged low rates relative to other periods. When conducting this analysis in the next sub-section, we use a combination of criteria to define periods of

\footnotetext{
${ }^{25}$ Even if the dip in these measures initially resulted from an economic downturn or macro-financial instability.
} 
prolonged low rates. The first is that the short-term yield, as reflected in the three-month treasury bill rate, be below one percent. The second is that the "on-the-run," 10-year nominal government, bond yield is lower than the historical average of short-term policy interest rates. The reason for applying a double-threshold criterion is that it is typically satisfied only when both economic growth and nominal and real interest rates have been low for a considerable time.

Second, if periods of prolonged low rates are differentiated by the impact of an interest rate shock on earnings relative to other periods, one would expect, under rational expectations, for such shocks to result in a correspondingly different impact on bank equity valuations. Specifically, if (unanticipated) interest rate cuts result in weaker bank profitability under prolonged low rates but boost bank earnings at other times, then we should expect that bank equity values fall in response to negative interest rate surprises in times of prolonged low rates but rise otherwise. In this exercise reported in sub-section $\mathrm{C}$, we define a period of prolonged low rates as one where the 10-year government bond yield is below two percent, a threshold level at which the corresponding inflation-target adjusted "real" yield is at zero in many advanced economies. The historical average of monetary policy rates in most of these countries exceeds two percent, which makes the definition of prolonged low rates tighter in the bank equity valuation analysis relative to the bank profitability analysis. The double threshold criterion used to define periods of prolonged low rates in the earnings analysis is not appropriate for the equity valuation analysis. The additional constraint, on short-term yields cannot be used because these rates tend to be quite volatile in the high frequency, daily data utilized and, hence, movements around a threshold of such rates may not reflect a change in the interest rate regime.

\section{B. Impact of Low-for-long Episodes on Bank Profits}

\section{Empirical Framework}

The exercise covers almost 17,000 banks in 8 advanced economies, using annual data from the 1990s to $2015 .{ }^{26}$ Only banks with end-of-the-year financial statements are included. Data on earnings and other bank characteristics are obtained from Fitch Connect; data on interest rates and macroeconomic variables are obtained from the International Financial Statistics, Haver analytics and Thomson Reuters Datastream. ${ }^{27}$

\footnotetext{
${ }^{26}$ Canada, Finland, France, Germany, Japan, Netherlands, United Kingdom, and United States. The country coverage is mainly subject to the data availability of term premiums.

${ }^{27}$ See Annex for a detailed description of the variables and data sources.
} 
The drivers of bank profits are evaluated using the following regression:

$$
\begin{aligned}
& \text { Profit }_{i j t}=\alpha_{i}+\theta_{t}+\rho \text { Profit }_{i j, t-1}+\theta_{\text {low }}+\gamma_{1} \text { Shortrate }_{j t}+\gamma_{2} \text { shortrate }_{j t} \times \\
& \operatorname{low}_{j t}+\gamma_{3} \mathrm{TP}_{j t}+\gamma_{4} \mathrm{TP}_{j t} \times \text { low }_{j t}+\beta \text { Macro }_{j t}+\tau \text { Policy }_{j, t-1}+\theta \text { Bankch }_{i j, t} / \\
& \text { Businessmodel }_{i j, t}+\varepsilon_{i j t} \text {, }
\end{aligned}
$$

in which Profit is measured by return on equity of bank $i$ in country $j$ in period $t$; low is the dummy for periods with prolonged low interest rates, which is defined by the double threshold criterion specified in the previous sub-section. The threshold for the long rate for all countries except Japan is set to be the historical average of the country-specific policy rates, while the one for Japan is at two percent; i.e., when the inflation-target, adjusted interest rate is at zero percent. ${ }^{28}$ Shortrate is the 3 -month interest rate, and TP denotes the term premium based on Wright (2011). ${ }^{29} \mathrm{~A}$ drop in short-term interest rates is ordinarily expected to increase bank profits through revaluation gains in the trading book and since it boosts income from fixed-rate lending. In periods of prolonged low rates when the short-term interest rate is likely to be near the ZLB and growth is low for an extended period, NIMs will be compressed following a decrease in short-term interest rates since banks have little room to lower deposit rates further. Moreover, lending may also not be boosted as much as in other periods where growth is higher.

The model controls for the macroeconomic and policy environment. In particular, Macro is a vector of regressors that includes CPI inflation, credit growth and GDP growth; and Policy controls for macroprudential policy, which is lagged to account for the time taken for it to effect bank earnings.

Bankch/businessmodel represents indicators of bank characteristics or business models. Two approaches are used to characterize business models. First, individual bank characteristics are considered, including size, leverage, the deposit funding ratio, the loansto-assets ratio, and the share of trading assets in total assets. Second, business models are constructed for each bank using a clustering approach in which business models are defined via three features: size, deposit funding ratio, and loan to asset ratio. Banks that are similar across these three dimensions are clustered into the same group, following the approach of Roengpitya, Tarashev and Tsatsaronis (2014). Three groups/types of business models are estimated and assigned to each bank at a time_-Wholesale-funded, diversified

\footnotetext{
${ }^{28}$ Since Japan has been in an environment with policy rates below two percent for most of the time in the sampling horizon, the historical average of policy rates is considered inappropriate for defining the ceiling of a period of low interest rates.
}

${ }^{29}$ IMF (2016), p.9. 
geographically and by business line; Deposit-funded, diversified by business line, domestic bank; and Deposit-funded domestic credit intermediary (Table 2). ${ }^{30}$

Time- and bank-fixed effects are included to consider other bank and institutional characteristics, as well as global factors that affect bank business. The baseline regression is estimated without considering bank characteristics or business models. Each extension includes one bank characteristic at a time or the dummies of two out of the three types of business models. For richer comparisons, a specification without a lagged dependent variable (LDV) is also estimated.

Sub-sample estimates of normal periods and periods of prolonged low interest rates are also provided as additional angle from which to view the different coefficients in the latter periods. Given that the time spans of the sub-samples are short, including a LDV may bias the coefficients; nonetheless, additional estimates with GMM estimators using ArellanoBover/Blundell-Bond and Arellano-Bond approach are conducted as robustness check.

\section{Table 2. Classification of Bank Business Models}

\begin{tabular}{lccc}
\hline & $\begin{array}{c}\text { Business Model 1 } \\
\text { Wholesale funded, } \\
\text { diversified geographically } \\
\text { and by business line }\end{array}$ & $\begin{array}{c}\text { Business Model 2 } \\
\text { Deposit funded } \\
\text { domestic credit } \\
\text { intermediary }\end{array}$ & $\begin{array}{c}\text { Business Model 3 } \\
\text { Deposit funded, diversified } \\
\text { by business line, domestic } \\
\text { bank }\end{array}$ \\
\hline Average Size (billions of U.S. dollars) & 42 & 3 & 2 \\
Average Loan-to-Asset Ratio (percent) & 47 & 73 & 43 \\
Average Deposit Funding Ratio (percent) $^{\text {Average Share of Foreign Income (percent) }}{ }^{1}$ & 25 & 88 & 92 \\
\hline
\end{tabular}

Sources: Bloomberg L.P.; Fitch; and IMF staff calculations.

${ }^{1}$ Data available for a significantly smaller subset of banks.

\section{Results}

The focus of this exercise is the impact of interest rate levels on bank profits in low-for-long periods and the role of bank characteristics in driving profits in these periods. In normal periods, ROE increases in response to an interest rate drop, indicating that lending could be boosted by lower rates, the interest margin is not likely to be compressed, and possibly also, more investment income from the trading book (Table 3). Specifically, a one percent drop in the interest rate leads to around 0.3 percent increase in the ROE. By contrast, in periods with

\footnotetext{
${ }^{30}$ Clustering methods generally classify observations to minimize the distance between observations within the same cluster and maximize distance between observations in different clusters. The distance used is the traditional L-2 distance, which calculates distance based on the sum of squares.
} 
prolonged low interest rates, ROE drops following a fall in interest rates. Moreover, profits are much more sensitive to interest rate changes, as a decrease of the same magnitude in interest rates as in a normal period results in an almost one percent drop in profit, which is significantly larger than the response in normal periods. This possibly reflects the interest rate compression when the rate hits the $\mathrm{ZLB}$, and the lack of a boost in lending arising from any interest rate adjustment in this period when growth is low. Sub-sample estimates using GMM estimators also confirms this finding, showing an even a larger difference in the sensitivity of profits to interest rates in normal and low-for-long periods. In general, the sign and significance of the interest rate coefficients, are remarkably stable across different specifications and estimation methods.

Lower term premiums tend to reduce bank profits in normal times, with statistically significant coefficients in the baseline specification and the ones with a LDV, controlling for macroprudential policy. However, this is not always supported by the regressions with some bank characteristics and sub-samples.

Estimates show that bank characteristics do matter for the profitability periods of prolonged, low interest rates. Banks that are more leveraged, rely more on deposit funding, and have more trading assets, tend to experience a significantly bigger dent in their profits in such periods. For example, taking more leverage and holding more trading assets have statistically significant and positive effects on banks' earnings in ordinary times, but such positive effects are reversed in periods of prolonged low rates, suggesting that business models with these characteristics may face a greater viability challenge during such times. Also, a one percent increase in the share of deposit funding more than doubles the negative impact of a decline in short-term interest rates on bank returns in periods of prolonged low rates. The greater vulnerability of deposit-funded banks to interest rate decreases during periods of prolonged low rates is likely to reflect the compression in NIMs at the ZLB of deposit rates. Clustering banks by business models confirms these results. Large, internationally more diversified wholesale-funded banks tend to outperform other types of banks during periods of prolonged low rates. Their estimated average profit is 0.7 percentage points higher than deposit-funded domestic banks with small lending portfolios, which have the lowest estimated average profits during such episodes.

Other controls have expected signs. For example, macroprudential policy has a significant impact on bank profits, indicating that more intense policy leads to profit reductions down the line.

The baseline results are robust to a number of perturbations of this benchmark specification, including using other bank business characteristics, using alternative definitions of periods of prolonged low interest rates, using lagged values of bank business model characteristics, and 
controlling for concentration in the banking industry. The baseline specification is also robust to estimation using different types of GMM estimator, as shown in Table 4.

\begin{tabular}{|c|c|c|c|c|c|c|c|c|}
\hline \multicolumn{9}{|c|}{$\begin{array}{l}\text { Table 3. Impact of Low-for-long Episodes on Bank Profits: Main Results } \\
\text { Dependent variable: ROE }\end{array}$} \\
\hline & $(1)$ & $(2)$ & (3) & (4) & (5) & $(6)$ & $(7)$ & (8) \\
\hline VARIABLES & Baseline & $\begin{array}{l}\text { No LDV or } \\
\text { Macroprud. }\end{array}$ & $\begin{array}{c}\text { Bank } \\
\text { Characteristics }\end{array}$ & $\begin{array}{c}\text { Bank } \\
\text { Characteristics }\end{array}$ & $\begin{array}{c}\text { Bank } \\
\text { Characteristics }\end{array}$ & $\begin{array}{c}\text { Bank } \\
\text { Characteristics }\end{array}$ & $\begin{array}{c}\text { Bank } \\
\text { Characteristics }\end{array}$ & $\begin{array}{c}\text { Business } \\
\text { model }\end{array}$ \\
\hline ROE (lag) & $\begin{array}{l}0.422^{* * *} \\
(0.00223)\end{array}$ & & $\begin{array}{l}0.413^{* * *} \\
(0.00478)\end{array}$ & $\begin{array}{l}0.422 * * * \\
(0.00471)\end{array}$ & $\begin{array}{l}0.433 * * * \\
(0.00466)\end{array}$ & $\begin{array}{l}0.423 * * * \\
(0.00478)\end{array}$ & $\begin{array}{l}0.240^{* * *} \\
(0.00773)\end{array}$ & $\begin{array}{l}0.433 * * * \\
(0.00465)\end{array}$ \\
\hline Low*ROE (lag) & $\begin{array}{c}0.000930 * * * \\
(0.000343)\end{array}$ & & $\begin{array}{l}0.000939 \\
(0.00138)\end{array}$ & $\begin{array}{l}0.000946 \\
(0.00136)\end{array}$ & $\begin{array}{l}0.000835 \\
(0.00135)\end{array}$ & $\begin{array}{l}0.000874 \\
(0.00136)\end{array}$ & $\begin{array}{l}0.000743 \\
(0.00197)\end{array}$ & $\begin{array}{l}0.000839 \\
(0.00134)\end{array}$ \\
\hline CPI inflation & $\begin{array}{c}0.00716^{* * *} \\
(0.000696)\end{array}$ & $\begin{array}{l}0.0140 * * * \\
(0.000679)\end{array}$ & $\begin{array}{c}0.00788^{* * *} \\
(0.00105)\end{array}$ & $\begin{array}{c}0.00742^{* * *} \\
(0.00105)\end{array}$ & $\begin{array}{c}0.00561^{* * *} \\
(0.00106)\end{array}$ & $\begin{array}{c}0.00556 * * * \\
(0.00105)\end{array}$ & $\begin{array}{c}0.00475 \\
(0.00560)\end{array}$ & $\begin{array}{c}0.00535^{* * *} \\
(0.00105)\end{array}$ \\
\hline Credit to GDP ratio & $\begin{array}{c}-0.000597 * * * \\
(4.22 \mathrm{e}-05)\end{array}$ & $\begin{array}{c}-0.000715^{* * *} \\
(4.36 \mathrm{e}-05)\end{array}$ & $\begin{array}{c}-0.000574^{* * *} \\
(5.87 \mathrm{e}-05)\end{array}$ & $\begin{array}{c}-0.000596 * * * \\
(5.81 \mathrm{e}-05)\end{array}$ & $\begin{array}{c}-0.000658^{* * *} \\
(5.95 \mathrm{e}-05)\end{array}$ & $\begin{array}{c}-0.000662 * * * \\
(6.01 \mathrm{e}-05)\end{array}$ & $\begin{array}{c}-8.91 \mathrm{e}-05 \\
(0.000269)\end{array}$ & $\begin{array}{c}-0.000646 * * * \\
(5.99 \mathrm{e}-05)\end{array}$ \\
\hline Real GDP growth & $\begin{array}{c}0.00207 \\
(0.00170)\end{array}$ & $\begin{array}{c}0.00591 * * * \\
(0.00177)\end{array}$ & $\begin{array}{l}0.00399^{*} \\
(0.00214)\end{array}$ & $\begin{array}{c}0.00235 \\
(0.00213)\end{array}$ & $\begin{array}{c}0.00168 \\
(0.00211)\end{array}$ & $\begin{array}{c}0.00235 \\
(0.00215)\end{array}$ & $\begin{array}{r}-0.00212 \\
(0.0132)\end{array}$ & $\begin{array}{c}0.00168 \\
(0.00211)\end{array}$ \\
\hline MacroPrud. Regulation (lag) & $\begin{array}{c}-0.0165^{* * *} \\
(0.00569)\end{array}$ & & $\begin{array}{l}-0.0179 * * \\
(0.00719)\end{array}$ & $\begin{array}{l}-0.0175^{* *} \\
(0.00721)\end{array}$ & $\begin{array}{l}-0.0207^{* *} \\
(0.00810)\end{array}$ & $\begin{array}{c}-0.0223 * * * \\
(0.00776)\end{array}$ & $\begin{array}{c}-0.0510^{* *} \\
(0.0259)\end{array}$ & $\begin{array}{c}-0.0212^{* * *} \\
(0.00821)\end{array}$ \\
\hline 3-month interest rate & $\begin{array}{c}-0.00273^{* * *} \\
(0.000445)\end{array}$ & $\begin{array}{c}-0.00304 * * * \\
(0.000421)\end{array}$ & $\begin{array}{c}-0.00296 * * * \\
(0.000618)\end{array}$ & $\begin{array}{c}-0.00279 * * * \\
(0.000617)\end{array}$ & $\begin{array}{c}-0.00232 * * * \\
(0.000618)\end{array}$ & $\begin{array}{c}-0.00204 * * * \\
(0.000613)\end{array}$ & $\begin{array}{l}-0.00231 \\
(0.00269)\end{array}$ & $\begin{array}{c}-0.00220 * * * \\
(0.000612)\end{array}$ \\
\hline Term premium & $\begin{array}{c}0.00296 * * \\
(0.00127)\end{array}$ & $\begin{array}{c}2.78 \mathrm{e}-05 \\
(0.00127)\end{array}$ & $\begin{array}{c}0.00439 * * * \\
(0.00167)\end{array}$ & $\begin{array}{c}0.00335^{* *} \\
(0.00168)\end{array}$ & $\begin{array}{c}0.00167 \\
(0.00177)\end{array}$ & $\begin{array}{l}0.00320^{*} \\
(0.00173)\end{array}$ & $\begin{array}{l}-0.0175^{* *} \\
(0.00729)\end{array}$ & $\begin{array}{c}0.00216 \\
(0.00175)\end{array}$ \\
\hline Low & $\begin{array}{c}0.00696 \\
(0.00468)\end{array}$ & $\begin{array}{c}-0.0379 * * * \\
(0.00466)\end{array}$ & $\begin{array}{c}0.0200 * * * \\
(0.00633)\end{array}$ & $\begin{array}{c}0.0101^{*} \\
(0.00615)\end{array}$ & $\begin{array}{c}0.0335 * * * \\
(0.00767)\end{array}$ & $\begin{array}{l}0.0188 * * \\
(0.00769)\end{array}$ & $\begin{array}{l}-0.0181 \\
(0.0252)\end{array}$ & $\begin{array}{c}0.0200 * * * \\
(0.00719)\end{array}$ \\
\hline Low*3-month interest rate & $\begin{array}{c}0.0126^{* * *} \\
(0.00369)\end{array}$ & $\begin{array}{l}0.0330^{* * *} \\
(0.00346)\end{array}$ & $\begin{array}{c}0.0151^{* * *} \\
(0.00453)\end{array}$ & $\begin{array}{l}0.0140^{* * *} \\
(0.00455)\end{array}$ & $\begin{array}{l}0.00922^{*} \\
(0.00478)\end{array}$ & $\begin{array}{l}0.0124^{* * *} \\
(0.00462)\end{array}$ & $\begin{array}{c}0.0605^{* * *} \\
(0.0166)\end{array}$ & $\begin{array}{l}0.0110^{* *} \\
(0.00471)\end{array}$ \\
\hline Low*term premium & $\begin{array}{l}0.000836 \\
(0.00168)\end{array}$ & $\begin{array}{l}0.00842^{* * *} \\
(0.00178)\end{array}$ & $\begin{array}{l}-0.00153 \\
(0.00225)\end{array}$ & $\begin{array}{l}0.000473 \\
(0.00227)\end{array}$ & $\begin{array}{l}-0.00421 \\
(0.00261)\end{array}$ & $\begin{array}{l}-0.00311 \\
(0.00259)\end{array}$ & $\begin{array}{c}0.0233^{* *} \\
(0.0108)\end{array}$ & $\begin{array}{c}-0.00411 \\
(0.00262)\end{array}$ \\
\hline Size & & & $\begin{array}{l}0.0102 * * * \\
(0.000922)\end{array}$ & & & & & \\
\hline Low*size & & & $\begin{array}{c}-0.00155^{* * *} \\
(0.000308)\end{array}$ & & & & & \\
\hline Leverage & & & & $\begin{array}{c}0.000154^{* *} \\
(6.26 \mathrm{e}-05)\end{array}$ & & & & \\
\hline Low*leverage & & & & $\begin{array}{c}-0.000249 * * * \\
(9.60 \mathrm{e}-05)\end{array}$ & & & & \\
\hline Depositfunding & & & & & $\begin{array}{c}-0.0134^{* * *} \\
(0.00434)\end{array}$ & & & \\
\hline Low*depositfunding & & & & & $\begin{array}{c}-0.0148 * * * \\
(0.00386)\end{array}$ & & & \\
\hline Loan to asset ratio & & & & & & $\begin{array}{c}0.0497 * * * \\
(0.00722)\end{array}$ & & \\
\hline Low*loantoasset & & & & & & $\begin{array}{l}-0.00501 \\
(0.00709)\end{array}$ & & \\
\hline Trading asset ratio & & & & & & & $\begin{array}{c}0.0567^{* * *} \\
(0.00807)\end{array}$ & \\
\hline Low*tradingassets & & & & & & & $\begin{array}{c}-0.0651 * * * \\
(0.00610)\end{array}$ & \\
\hline Wholesale-funded-trading banks & & & & & & & & $\begin{array}{c}0.00221 \\
(0.00267)\end{array}$ \\
\hline Deposit-funded-lending banks & & & & & & & & $\begin{array}{l}0.00849 * * * \\
(0.000742)\end{array}$ \\
\hline Low*wholesale-funded-trading banks & & & & & & & & $\begin{array}{l}0.00774 * * \\
(0.00324)\end{array}$ \\
\hline Low*deposit-funded-lending banks & & & & & & & & $\begin{array}{l}0.00180^{* *} \\
(0.000919)\end{array}$ \\
\hline Constant & $\begin{array}{l}0.121^{* * *} \\
(0.00994)\end{array}$ & $\begin{array}{l}0.169 * * * \\
(0.0106)\end{array}$ & $\begin{array}{c}0.0636 * * * \\
(0.0139)\end{array}$ & $\begin{array}{l}0.116^{* * *} \\
(0.0129)\end{array}$ & $\begin{array}{c}0.144 * * * \\
(0.0138)\end{array}$ & $\begin{array}{c}0.0993^{* * *} \\
(0.0137)\end{array}$ & $\begin{array}{r}0.144^{* * *} \\
(0.0534)\end{array}$ & $\begin{array}{l}0.126 * * * \\
(0.0134)\end{array}$ \\
\hline Observations & 181,358 & 199,174 & 181,358 & 181,358 & 177,644 & 179,428 & 71,281 & 177,446 \\
\hline R-squared & 0.290 & 0.117 & 0.292 & 0.290 & 0.303 & 0.300 & 0.193 & 0.304 \\
\hline Number of fitchentityid & 16,497 & 16,862 & 16,497 & 16,497 & 16,075 & 16,284 & 10,939 & 16,046 \\
\hline Time fixed effect & YES & YES & YES & YES & YES & YES & YES & YES \\
\hline Number groups & 16497 & 16862 & 16497 & 16497 & 16075 & 16284 & 10939 & 16046 \\
\hline $\begin{array}{l}\text { Standard errors in parentheses } \\
* * * p<0.01,{ }^{* *} p<0.05, * p<0.1\end{array}$ & & & & & & & & \\
\hline
\end{tabular}




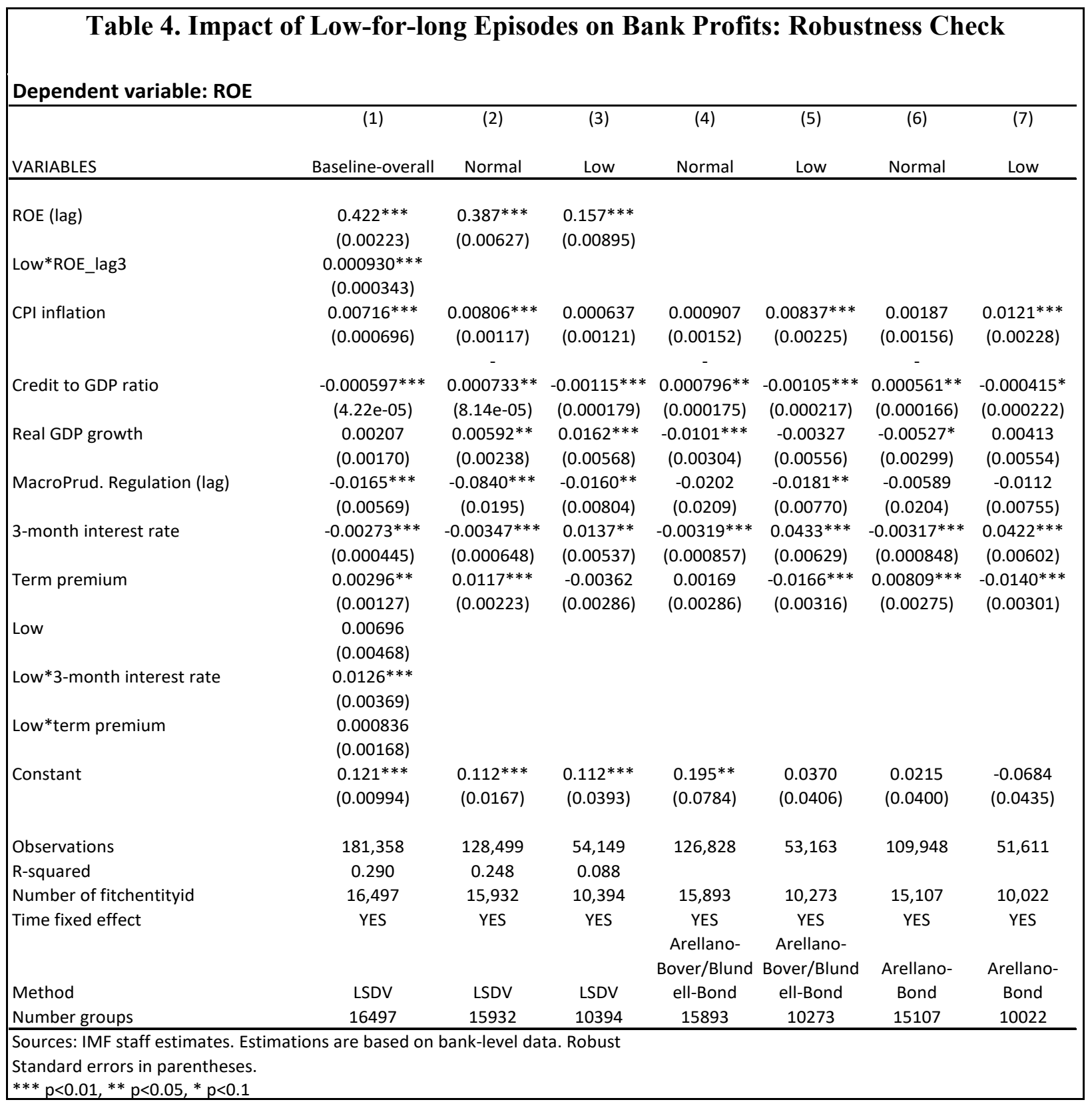




\section{Impact of Changes in Expectations Regarding Low-for-Long Scenarios on Banks' Equity Values}

\section{Empirical Framework}

The analysis relies on daily data spanning the period 2000-2016, for 16 advanced economies, with coverage underpinned by availability of data on forward rates and term premia. ${ }^{31}$ Equity price data are from Bloomberg. Only banks whose shares were frequently traded were kept, using the inclusion in the Fitch Connect dataset as a criterion.

The relationship estimated is:

$$
\begin{aligned}
& \text { Equity Price Return } \\
& \qquad \begin{aligned}
& i j t \\
& \\
&+\gamma_{1} \text { suprise }_{j t} \times \text { MP_normaltime }_{j t}+\gamma_{2} \text { suprise }_{j t} \times \text { MP_low }_{j t} \\
&+\theta \text { conditioning variable }_{j t}+\varepsilon_{i j t}
\end{aligned}
\end{aligned}
$$

in which the dependent variable, equity price return, is the daily change in equity prices (in logarithm). Marketreturn denotes the change in country specific stock market indices, capturing the overall market return (in logarithm). Surprise represents unexpected changes in market expectations of future short-term interest rates, defined as the change in the country specific 9-year-ahead, one-year-forward rate. MP_low is the dummy for monetary policy announcement dates in periods with prolonged low rates, while MP_normaltime represents the announcement dates in other periods.

The interaction term suprise j $_{j t} \times M P_{-}$normaltime $_{j t}$ and suprise $_{j t} \times M P_{-}$low $_{j t}$ measure the market surprises on the expected future short-term rate on the monetary policy announcement days. This is either the surprise triggered by the news about changes in the monetary policy stance, or a correction of previously held expectations when there is no change in the policy on that day. If there are no other major announcements on the same day, an assumption we make, these interaction terms ensure exogeneity of the interest rate shock.

The empirical model is estimated with all banks, and banks with 3 business models respectively. These include deposit-funded domestic credit intermediaries; banks that are wholesale-funded, diversified geographically and by business line; and deposit-funded banks that are diversified by business line and whose client-base is primarily domestic. Banks types are identified by clustering methods. After identifying the business model of each bank, the business model IDs are applied to all banks in this exercise.

\footnotetext{
${ }^{31}$ Australia, Belgium, United Kingdom, Canada, Denmark, Finland, France, Germany, Ireland, Italy, Japan, the Netherlands, Spain, Sweden, Switzerland, and United States.
} 


\section{Results}

Monetary easing surprises affect bank equity returns differently in periods of prolonged low interest rates compared to other ("normal") periods (Table 5). First, decreases in forward rates have a negative effect on bank equity returns on average. This is intuitive because lower interest rates are likelier to imply the advent of recessionary conditions in the future which is associated with a bleaker earnings outlook for banks and hence with lower equity returns. Second, decreases in forward rates on monetary policy (committee) meeting dates, which are interpreted as monetary easing surprises lower bank equity returns during periods of prolonged low rates even as they boost these equity returns in other periods. More specifically, Table 5 shows that monetary easing surprises during periods of prolonged low interest rates negatively impact bank equity returns by more than twice the magnitude relative to such surprises in other periods. The results also show that monetary easing surprises during other periods boosts bank equity returns.

These findings are consistent with the results reported in the previous sub-section. Specifically, since a decrease in interest rates tends to portend a significantly more negative outlook for bank earnings in periods of prolonged low rates, monetary easing surprises should be expected to have a correspondingly more enervating effect on bank equity returns.

Moreover, the result could also be interpreted as the outcome of different economic interpretation of interest rate cuts in periods of prolonged low rates relative to normal periods. During normal economic times, unexpected monetary easing generates expectations of higher economic activity and asset returns, of fewer nonperforming loans, and of higher spread income on fixed-rate assets and loans, all of which increase expected bank profits. However, monetary easing surprises during episodes of prolonged low rates are more likely to be interpreted as further extension of the time over which insipid growth and bank earnings are likely to persist, which, in turn, results in further pressure on bank equity values.

The results are differentiated along bank business models. Larger, more diversified, and more-wholesale-funded banks are less sensitive to monetary policy news during periods of prolonged low rates. This outcome may reflect the market's recognition of such banks' greater ability to adapt to changing domestic economic prospects. In contrast, the response of equity returns confirms their greater sensitivity to bad news about the domestic economy during prolonged low rates. (Figure 4).

Endogeneity may be present when including the surprise in the regression. Because other economic news that change the expectations of forward rates may also directly affect the equity price return. The missing variable of other news in the residual could possibly correlate with the surprise and result in bias estimates. Therefore, a number of robustness checks were conducted, including an event study (regression on dates with monetary policy 
announcements) and using a monetary surprise measure constructed to be orthogonal to other economic news. ${ }^{32}$ Both exercises confirm that the main results are robust (Table 5).

\section{Figure 4. Impact of Forward Rate Surprises on Bank Equity Returns (percent)}

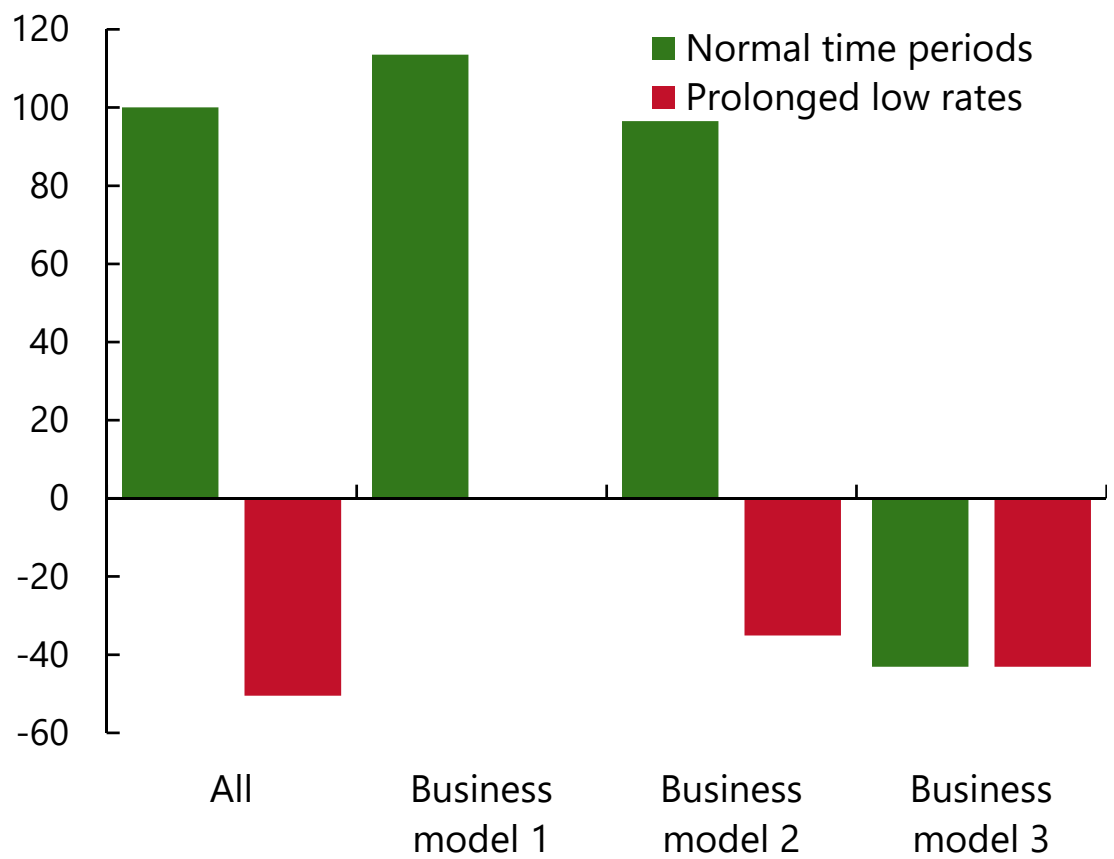

Sources: Bloomberg L.P.; Fitch Connect; IMF, Monetary and Financial Statistics; Thomson Reuters Datastream; and IMF staff calculations.

Note: The figure depicts the estimated impact of a one percentage point surprise decrease in forward interest rates, occurring on monetary policy announcement dates, on the daily equity returns of banks relative to the estimated sample average impact of such surprises during periods of normal interest rates. For example, the left-most bar is the relative magnitude of the estimated impact on banks' daily equity return of forward rate surprises during normal periods, and so is equal to 100 percent. Only statistically significant impact estimates are depicted as non-zero values. Business models are as defined in Table 2. Further details of the methodology are provided in Section IV B and coefficients are in Table 5 (Baseline).

\footnotetext{
${ }^{32}$ This measure extracts the component in surprise that is orthogonal to market return, which represents news that affect the interest rate expectation but not directly affect the equity price return.
} 


\begin{tabular}{|c|c|c|c|c|c|c|c|c|c|c|c|c|}
\hline \multicolumn{13}{|c|}{ Table 5. Impact of Changes in Expectations Regarding a Low-for-Long Scenarios on Bank Equity Price Return } \\
\hline \multicolumn{13}{|l|}{ Dependent Variable: Equity Price Return } \\
\hline \multirow{4}{*}{ VARIABLES } & $(1)$ & (2) & (3) & (4) & (5) & (6) & \multirow{2}{*}{ Baseline } & (8) & (9) & (10) & (11) & (12) \\
\hline & & $\begin{array}{l}\text { Orthogonal } \\
\text { suprise }\end{array}$ & Event Study & & $\begin{array}{l}\text { Orthogonal } \\
\text { suprise }\end{array}$ & & & Orthogonal & & \multirow{2}{*}{\multicolumn{2}{|c|}{$\begin{array}{cc}\text { Orthogonal } \\
\text { Buseline }\end{array}$}} & \multirow{2}{*}{ Event Study } \\
\hline & \multirow{2}{*}{\multicolumn{3}{|c|}{ All Banks }} & Baseline & & Event Study & \multirow{2}{*}{\multicolumn{3}{|c|}{$\begin{array}{c}\text { Wholesale-funded, diversified } \\
\text { geographically and by business line } \\
\text { banks }\end{array}$}} & & & \\
\hline & & & & \multicolumn{3}{|c|}{$\begin{array}{c}\text { Deposit-funded domestic credit } \\
\text { intermediary }\end{array}$} & & & & \multicolumn{3}{|c|}{$\begin{array}{l}\text { Deposit-funded, diversified by business } \\
\text { line, domestic bank }\end{array}$} \\
\hline Market return & $\begin{array}{c}0.491^{* * *} \\
(0.0179)\end{array}$ & $\begin{array}{l}0.494^{* * *} \\
(0.0179)\end{array}$ & $\begin{array}{l}0.617^{* * *} \\
(0.0244)\end{array}$ & $\begin{array}{l}0.475 * * * \\
(0.0197)\end{array}$ & $\begin{array}{l}0.479 * * * \\
(0.0196)\end{array}$ & $\begin{array}{l}0.623 * * * \\
(0.0276)\end{array}$ & $\begin{array}{l}0.826 * * * \\
(0.0638)\end{array}$ & $\begin{array}{l}0.826 * * * \\
(0.0638)\end{array}$ & $\begin{array}{l}0.865^{* * *} \\
(0.0721)\end{array}$ & $\begin{array}{l}0.347^{* * *} \\
(0.0400)\end{array}$ & $\begin{array}{l}0.353^{* * *} \\
(0.0399)\end{array}$ & $\begin{array}{l}0.433^{* * *} \\
(0.0588)\end{array}$ \\
\hline Suprise(9y forward) & $\begin{array}{l}0.00237^{* * *} \\
(0.000334)\end{array}$ & & & $\begin{array}{l}0.00304 * * * \\
(0.000273)\end{array}$ & & & $\begin{array}{c}0.000651 \\
(0.000951)\end{array}$ & & & $\begin{array}{l}0.00373 * * * \\
(0.000790)\end{array}$ & & \\
\hline suprise(9y forward)* MP in normal(2 pc) & $\begin{array}{c}-0.0110^{* * *} \\
(0.00187)\end{array}$ & & $\begin{array}{c}-0.00884 * * * \\
(0.00190)\end{array}$ & $\begin{array}{c}-0.0114^{* * *} \\
(0.00210)\end{array}$ & & $\begin{array}{c}-0.00946 * * * \\
(0.00216)\end{array}$ & $\begin{array}{c}-0.00982^{* * *} \\
(0.00281)\end{array}$ & & $\begin{array}{c}-0.00894 * * * \\
(0.00258)\end{array}$ & $\begin{array}{l}-0.00386 \\
(0.00511)\end{array}$ & & $\begin{array}{l}-0.00144 \\
(0.00502)\end{array}$ \\
\hline suprise(9y forward)* MP in low(2 pc) & $\begin{array}{l}0.00200 * * * \\
(0.000693)\end{array}$ & & $\begin{array}{l}0.00249 * * * \\
(0.000807)\end{array}$ & $\begin{array}{c}0.000244 \\
(0.000574)\end{array}$ & & $\begin{array}{c}0.00120^{*} \\
(0.000635)\end{array}$ & $\begin{array}{c}0.00137 \\
(0.00223)\end{array}$ & & $\begin{array}{c}0.00143 \\
(0.00255)\end{array}$ & $\begin{array}{c}0.00181 \\
(0.00217)\end{array}$ & & $\begin{array}{l}0.00396^{*} \\
(0.00237)\end{array}$ \\
\hline Change in VIX & $\begin{array}{l}0.0110^{* * *} \\
(0.00126)\end{array}$ & $\begin{array}{l}0.0110^{* * *} \\
(0.00126)\end{array}$ & $\begin{array}{l}0.0220^{* * *} \\
(0.00441)\end{array}$ & $\begin{array}{c}0.00664 * * * \\
(0.00146)\end{array}$ & $\begin{array}{c}0.00668^{* * *} \\
(0.00147)\end{array}$ & $\begin{array}{l}0.0163^{* * *} \\
(0.00260)\end{array}$ & $\begin{array}{c}-0.00736^{* * *} \\
(0.00224)\end{array}$ & $\begin{array}{c}-0.00733 * * * \\
(0.00224)\end{array}$ & $\begin{array}{l}-0.00268 \\
(0.00492)\end{array}$ & $\begin{array}{c}0.00428 \\
(0.00309)\end{array}$ & $\begin{array}{c}0.00430 \\
(0.00309)\end{array}$ & $\begin{array}{l}0.00356 \\
(0.00620)\end{array}$ \\
\hline Change in oil price & $\begin{array}{l}0.000571 \\
(0.00153)\end{array}$ & $\begin{array}{l}0.000559 \\
(0.00153)\end{array}$ & $\begin{array}{l}-0.00367 \\
(0.00708)\end{array}$ & $\begin{array}{l}-0.00210 \\
(0.00161)\end{array}$ & $\begin{array}{l}-0.00211 \\
(0.00161)\end{array}$ & $\begin{array}{c}0.00143 \\
(0.00553)\end{array}$ & $\begin{array}{c}0.00380 \\
(0.00461)\end{array}$ & $\begin{array}{c}0.00374 \\
(0.00461)\end{array}$ & $\begin{array}{l}0.00566 \\
(0.0141)\end{array}$ & $\begin{array}{l}0.0114^{* *} \\
(0.00555)\end{array}$ & $\begin{array}{l}0.0113^{* *} \\
(0.00555)\end{array}$ & $\begin{array}{c}0.0101 \\
(0.00994)\end{array}$ \\
\hline suprise(9y forward orth.3) & & $\begin{array}{l}0.00247^{* * *} \\
(0.000333)\end{array}$ & & & $\begin{array}{l}0.00316 * * * \\
(0.000275)\end{array}$ & & & $\begin{array}{c}0.000676 \\
(0.000949)\end{array}$ & & & $\begin{array}{l}0.00387^{* * *} \\
(0.000789)\end{array}$ & \\
\hline suprise(9y forward orth. 3$)^{*} \mathrm{MP}$ at non $|4|(2 \mathrm{pc}$ & & $\begin{array}{c}-0.0112^{* * *} \\
(0.00192)\end{array}$ & & & $\begin{array}{c}-0.0121^{* * *} \\
(0.00217)\end{array}$ & & & $\begin{array}{c}-0.0102^{* * *} \\
(0.00260)\end{array}$ & & & $\begin{array}{l}-0.00433 \\
(0.00486)\end{array}$ & \\
\hline suprise(9y forward orth.3)* MP at $|4|(2 \mathrm{pc})$ & & $\begin{array}{l}-0.000269 \\
(0.000624)\end{array}$ & & & $\begin{array}{c}-0.00198^{* * *} \\
(0.000555)\end{array}$ & & & $\begin{array}{c}0.00127 \\
(0.00220)\end{array}$ & & & $\begin{array}{l}-0.00174 \\
(0.00202)\end{array}$ & \\
\hline Constant & $\begin{array}{c}-0.000171^{* * *} \\
(2.14 \mathrm{e}-06)\end{array}$ & $\begin{array}{c}-0.000175^{* * *} \\
(2.06 \mathrm{e}-06)\end{array}$ & $\begin{array}{c}-0.000437^{* * *} \\
(8.76 \mathrm{e}-05)\end{array}$ & $\begin{array}{c}-7.16 \mathrm{e}-05^{* * *} \\
(2.40 \mathrm{e}-06)\end{array}$ & $\begin{array}{c}-7.70 \mathrm{e}-05^{* * * *} \\
(2.32 \mathrm{e}-06)\end{array}$ & $\begin{array}{l}-1.55 \mathrm{e}-05 \\
(7.95 \mathrm{e}-05)\end{array}$ & $\begin{array}{c}-0.000156^{* * *}- \\
(3.10 \mathrm{e}-06)\end{array}$ & $\begin{array}{c}*-0.000156^{* * *} \\
(3.29 \mathrm{e}-06)\end{array}$ & $\begin{array}{c}0.000159 * * * \\
(3.24 \mathrm{e}-05)\end{array}$ & $\begin{array}{c}7.85 \mathrm{e}-05^{* * *} \\
(7.51 \mathrm{e}-06)\end{array}$ & $\begin{array}{c}7.33 \mathrm{e}-05^{* * *} \\
(7.24 \mathrm{e}-06)\end{array}$ & $\begin{array}{c}-4.10 \mathrm{e}-06 \\
(0.000185)\end{array}$ \\
\hline Observations & $3,110,571$ & $3,110,571$ & 118,455 & $1,786,738$ & $1,786,738$ & 68,244 & 215,486 & 215,486 & 10,136 & 329,095 & 329,095 & 11,918 \\
\hline R-squared & 0.011 & 0.011 & 0.025 & 0.023 & 0.023 & 0.055 & 0.090 & 0.090 & 0.229 & 0.005 & 0.005 & 0.053 \\
\hline Number of firm ID & 889 & 889 & 889 & 749 & 749 & 749 & 98 & 98 & 97 & 289 & 289 & 288 \\
\hline
\end{tabular}




\section{Discussion}

Notwithstanding the recent increase in long-term interest rates, the experience of Japan suggests that an imminent and permanent exit from a low interest rate environment may be challenging for several advanced economies. The combination of demographic changes and lower total factor productivity growth in these countries may represent important driving forces making for a steady state of low growth and low asset returns. Indeed, the longer-term decline in real interest rates since the mid-1980s suggests that natural rates may have fallen in response to such factors.

This paper shows that the implications for banking are likely significant. In the scenario of low natural rates, consolidation in the banking industry is likely in the long run. Small deposit-funded banks that are less internationally diversified tend to suffer the largest hit to profitability. Eventually, consolidation could result through the merger of smaller banks or of midsize banks with smaller banks, and industry concentration could rise through the exit of nonviable institutions. Merged banks would have lower average operational costs, be more diversified, and have greater market power - all of which may mean less incentive to take excessive risks. The resulting industry structure could be more efficient and stable. ${ }^{33}$

Tail risk exposure is expected to increase. Over the medium term, banks, especially those that are smaller and less diversified, may actively seek longer maturities for their assets. Although less interest rate volatility in the scenario softens the risk implications of such a strategy, a large positive interest rate shock can mean significant losses. Banks would also feel pressure to increase, within regulatory limits, their share of wholesale funding, a more volatile source of financing than retail deposits. This would be particularly true for larger banks, because the low-for-long environment provides strong incentives to use capital market financing, especially for international expansion. Such a development may affect prospects for financial stability in their home and host countries, depending on the modality of expansion. ${ }^{34}$

Demographic factors, low productivity growth, and advances in financial technology will likely cause significant shifts in banks' business lines under this scenario. When the population ages, especially in a context of reduced income growth, demand for household loans falls, and deposits tend to rise (Imam 2013). Aging will also increase demand for transaction services. However, if current trends in financial technology continue, the longtime preeminence of banks in payment services is not guaranteed. In addition, prospects for lending to domestic companies are also likely to be modest in this environment, because a shrinking population and low productivity imply fewer investment opportunities and lower

\footnotetext{
${ }^{33}$ Some of the efficiency losses from consolidation, including higher funding costs for nonfinancial firms and reduced relationship banking for small and medium-sized enterprises, would be balanced by the gains from more rational branch networks and lower operational costs. Stability benefits may be significant, particularly if forces for consolidation are not strong for the large banks, preventing a worsening of the too-big-to-fail problem. In practice, bank mergers do not always achieve the desired scale economies, and can be fraught with difficulties in integrating participating banks' infrastructures and cultures.

${ }^{34}$ For a comparison of the stability implications of cross-border lending and expansion through subsidiaries, see Chapter 2 of the April 2015 GFSR.
} 
loan demand. Finally, in a scenario of low rates, banks may lose market share in debt financing of larger companies, if financial technology allows nonbanks to price corporate credit risk, and low rates drive large firms to seek bond market funding. Consequently, business models of banks active in advanced economies may evolve toward fee-based and utility banking services even as fewer domestic lending opportunities motivate larger, internationally active banks to increase their exposure abroad, especially to emerging market economies.

In a scenario of low interest rates and low growth, policymakers must help enable a smooth adjustment of financial institutions' business models. This includes not hindering and, where feasible, actively facilitating consolidation for smaller institutions and liquidation of nonviable businesses where this is judged to be desirable from efficiency and financial stability perspectives. Prudential authorities would also need to contain incentives arising in a low-for-long steady-state that may increase exposure to tail risk given that banks may respond to incentives in this environment with wider maturity mismatches, higher leverage, or more wholesale funding. 


\section{REFERENCES}

Alessandri, P. and B. Nelson, 2012, "Simple Banking: Profitability and the Yield Curve," Working Paper 452. London: Bank of England.

Avdjiev, S., W. Du, C. Koch, and H-S. Shin, 2016, “The Dollar, Bank Leverage and the Deviation from Covered Interest Parity," Working Paper 592. Basel: Bank for International Settlements.

Bank of Japan, 2011, Financial Stability Report. Tokyo: Bank of Japan.

Bean, C., C. Broda, T. Ito, and R. Kroszner, 2015, "Low for Long? Causes and Consequences of Persistently Low Interest Rates", $17^{\text {th }}$ CEPR-ICMB Report on the World Economy.

Bernanke, B.S., 2005, "The Global Savings Glut and the U.S. Current Account Deficit, "Sandridge Lecture, Virginia Association of Economists, Richmond, VA (April 14). , 2015, “Why are Interest Rates So Low?” Brookings Blog.

Borio, C., L. Gambacorta and B. Hofmann, 2015, "The Influence of Monetary Policy on Bank Profitability,” Working Paper 514. Basel: Bank for International Settlements.

Brunnermeier, M.K. and Y. Koby, "The Reversal Interest Rate: The Effective Lower Bound of Monetary Policy," (in preparation). Available at: https://scholar.princeton.edu/markus/publications/reversal-interest-rate-effectivelower-bound-monetary-policy and Y. Sannikov, 2016, “The I-Theory of Money”, Working Paper 22533, Cambridge, MA: National Bureau of Economic Research.

Caballero, R., T. Hoshi and A. Kashyap, 2008, "Zombie Lending and Depressed Restructuring in Japan”, American Economic Review, vol. 98, no. 5, pp. 1943-77.

Carvalho, C., A. Ferrero and F. Nechio, 2016, "Demographics and Real Interest Rates: Exploring the Mechanism," European Economic Review, vol. 88, September, pp. 208-26.

Chodorow-Reich, G., 2014, "Effects of Unconventional Monetary Policy on Financial Institutions", Brookings Papers on Economic Activity, Spring, pp. 155-227.

Claessens, S., N. Coleman, and M. S. Donnelly (2017) “"Low-For-Long" Interest Rates and Banks' Interest Margins and Profitability: Cross-Country Evidence,” International Finance Discussion Papers 1197, Board of Governors of the Federal Reserve System.

Dell'Arriccia, G., L. Laeven and R. Marquez, 2014, "Real Interest Rates, Leverage and Bank Risk Taking," Journal of Economic Theory, vol. 149, pp. 65-99. 
and G. Suarez, 2017, “Bank Leverage and Monetary Policy’s Risk-Taking Channel: Evidence from the United States," Journal of Finance, vol. 72, no. 2, pp. 613-54.

Dreschler, I., A. Savov and P. Schnabl, 2017, "The Deposits Channel of Monetary Policy," Quarterly Journal of Economics, vol. 132, no. 4, pp. 1819-76.

English, W., S. van den Heuvel and E. Zakrajsek, 2012, "Interest Rate Risk and Bank Equity Valuations," Finance and Economics Discussion Series 2012-26. Washington, D.C.: Board of Governors of the Federal Reserve System.

European Systemic Risk Board, 2016, “Macroprudential Policy Issues Arising from Low Interest Rates and Structural Changes in the EU Financial System”.

Freixas, X. and J-C. Rochet, 2008, The Microeconomics of Banking, Cambridge, MA: The MIT Press.

Gambacorta, L., 2008, “How do Banks Set Interest Rates?” European Economic Review, vol. 52 , no. 5 , pp. 792.819.

Gordon, R., 2014, "The Demise of U.S. Economic Growth: Restatement, Rebuttal and Reflections," Working Paper 19895, Cambridge, MA: National Bureau of Economic Research.

Gourio, F. and P. Ngo, 2016, "Risk Premia at the ZLB: A Macroeconomic Interpretation," (in preparation). Available at: https://docs.google.com/viewer?a=v\&pid=sites\&srcid=ZGVmYXVsdGRvbWFpbnx mZ291cmlvfGd4OjI2MDhmMDIxMzY2ZDIxMTU

Graeve, F. D., O. De Jonghe, and R. V. Vennet, 2007, “Competition, Transmission and Bank Pricing Policies: Evidence from Belgian Loan and Deposit Markets" Journal of Banking and Finance, vol. 31, pp. 259. 278.

Holston, K., T. Laubach and J. Williams, 2016, "Measuring the Natural Rate of Interest: International Trends and Determinants," Working Paper 2016-11. San Francisco, CA: Federal Reserve Bank of San Francisco.

International Monetary Fund, 2014, "Perspectives on Global Real Interest Rates," chapter 3 of The World Economic Outlook, April, Washington, D.C.: International Monetary Fund.

, 2015, "International Banking After the Crisis: Increasingly Local and Safer," chapter 2 of The Global Financial Stability Report, April, Washington, D.C.: International Monetary Fund. 
,2016, "Financial Stability Challenges in a Low Growth, Low Rate Era," chapter 1 of The Global Financial Stability Report, October, Washington, D.C.: International Monetary Fund.

, 2017, "Low Growth, Low Interest Rates and Financial Intermediation," chapter 2 of The Global Financial Stability Report, April, Washington, D.C.: International Monetary Fund.

Katagiri, M., "The Equilibrium Yield Curve, the Phillips Curve and Monetary Policy," (forthcoming).

Lambert, F. and K. Ueda, 2014, "Effects of Unconventional Monetary Policy on Banking Sector Soundness," Working Paper 14/152. Washington, D.C.: International Monetary Fund.

Nagel, S., 2016, “The Liquidity Premium of Near Money Assets," Quarterly Journal of Economics, vol. 131, no. 4, pp. 1927-71.

Neumark, D., and S. A. Sharpe, 1992, "Market Structure and the Nature of Price Rigidity: Evidence from the Market for Consumer Deposits," Quarterly Journal of Economics, vol. 107, no. 2, pp. 657-80.

Nakata, T. and H. Tanaka, 2016, "Equilibrium Yield Curves and the Interest Rate Lower Bound," Finance and Economics Discussion Series 2016-085. Washington, D.C.: Board of Governors of the Federal Reserve System.

Piazzesi, M. and M. Schneider, 2007, "Equilibrium Yield Curves", NBER Macroeconomics Annual 2006, vol. 21, edited by D. Acemoglu, K. Rogoff and M. Woodford, pp. 389472. Cambridge, MA: The MIT Press.

Rachel, L. and T. Smith, 2015, "Secular Drivers of the Global Real Rate," Working Paper 571, London: Bank of England.

Roengpitya, R., N. Tarashev and K. Tsatsaronis, 2014, “Bank Business Models,” BIS Quarterly Review, December.

Saunders, A., and L. Schumacher, 2000, "The Determinants of Bank Interest Rate Margins: An International Study," Journal of International Money and Finance, vol. 19, pp. 813-32.

Summers, L., 2014, “U.S. Economic Prospects: Secular Stagnation, Hysteresis and the Zero Lower Bound," Business Economics, vol. 49, no. 2, pp. 65-73.

Viñals, J., S. Gray and K. Eckhold, 2016, "The Broader View: The Positive Effects of Negative Interest Rates.” Available at: https://blogs-imfdirect.imf.org/2016/04/10/thebroader-view-the-positive-view-of-negative-nominal-interest-rates. 
Appendix Table: Data Sources

\begin{tabular}{|c|c|c|}
\hline Variable & Description & Source \\
\hline Low & $\begin{array}{l}\text { Dummy for period with low interest rates, which is defined as the time when } \\
\text { the } 10 \text {-year government bond yield and the three-month short rate are } \\
\text { below their corresponding thresholds. The threshold for the } 10 \text {-year } \\
\text { government bond yield of all countries except Japan is set to be the } \\
\text { historical average of the country-specific policy rates (for Japan, it is set to } \\
\text { be } 2 \text { percent) when the real rate adjusted by the inflation target is at zero. } \\
\text { The threshold for the three-month interest rates is set to be } 1 \text { percent. }\end{array}$ & $\begin{array}{l}\text { Thomson Reuters Datastream and IMF } \\
\text { staff calculations }\end{array}$ \\
\hline Surprise (9-year forward) & $\begin{array}{l}\text { Daily change in the forward rate of the one-year government bond yield, } \\
\text { based on a no-arbitrage assumption and the spot rate of the 10-year and 9- } \\
\text { year government bond yield (from yield curve values for constant maturity). }\end{array}$ & $\begin{array}{l}\text { Thomson Reuters Datastream and IMF } \\
\text { staff calculations }\end{array}$ \\
\hline Surprise(9-year-forward orthogonal) & $\begin{array}{l}\text { Surprise that is orthogonal to market return, measured by the residual of } \\
\text { the regression of surprise on market return. }\end{array}$ & IMF staff calculations \\
\hline Monetary Policy in Low (2 percent) & $\begin{array}{l}\text { Dummy for period in low period and with monetary policy announcements. } \\
\text { The low period is defined as a period when the } 10 \text {-year government bond } \\
\text { yield is below } 2 \text { percent. }\end{array}$ & $\begin{array}{l}\text { Thomson Reuters Datastream, central } \\
\text { bank websites, and IMF staff } \\
\text { calculations }\end{array}$ \\
\hline Monetary Policy in Normal (2 percent) & $\begin{array}{l}\text { Dummy for period in non-low period and with monetary policy } \\
\text { announcements. The low period is defined as a period when the 10-year } \\
\text { government bond yield is below } 2 \text { percent. }\end{array}$ & $\begin{array}{l}\text { Thomson Reuters Datastream, central } \\
\text { bank websites, and IMF staff } \\
\text { calculations }\end{array}$ \\
\hline \multicolumn{3}{|l|}{ Bank Characteristics } \\
\hline Return on Equity & Earnings before interest and taxation divided by equity & Fitch Connect \\
\hline Size & Logarithm of banks' total assets & Fitch Connect \\
\hline Loan-to-Asset Ratio & Loan before impairment divided by total assets & Fitch Connect \\
\hline Deposit Funding Ratio & Customer deposit divided by total liability & Fitch Connect \\
\hline Trading Asset & Asset held for trading plus asset held at fair value & Fitch Connect \\
\hline Trading Asset Ratio & Trading asset divided by total asset & Fitch Connect \\
\hline Leverage Ratio & Total asset divided by equity & Fitch Connect \\
\hline \multicolumn{3}{|l|}{ Macroeconomic } \\
\hline Consumer Price Index Inflation & Year-on-year growth of consumer price index, percent & $\begin{array}{l}\text { IMF, International Financial Statistics } \\
\text { database }\end{array}$ \\
\hline Credit-to-GDP Ratio & Private-sector credit in percent of GDP & Bank for International Settlements \\
\hline Real GDP Growth & Year-over-year growth of GDP, constant prices & IMF, World Economic Outlook database \\
\hline Three-Month Interest Rate & Typically central bank bill/treasury bill yield or interbank offered rate & Haver Analytics \\
\hline Term Premium & Term premium estimated based on Wright (2011) & $\begin{array}{l}\text { IMF, Global Financial Stability Report, } \\
\text { October } 2016\end{array}$ \\
\hline Ten-Year Government Bond Yield & $\begin{array}{l}\text { On-the-run 10-year government bond yield (from yield curve values for } \\
\text { constant maturity) }\end{array}$ & Thomson Reuters Datastream \\
\hline Monetary Policy Rates & Short-term interest rates represent the monetary policy stance in a country & Haver Analytics \\
\hline \multicolumn{3}{|l|}{ Financial Market } \\
\hline Equity Price Return & Log difference of equity prices & \\
\hline Market Return & Difference of overall country-specific equity price indices & \\
\hline VIX & Chicago Board Options Exchange Market Volatility Index & Bloomberg L.P. \\
\hline Oil Price & Crude oil-West Texas Intermediate spot price & Bloomberg L.P. \\
\hline
\end{tabular}

Source: IMF staff. 